\title{
Gas6/Axl Signaling Activates the Phosphatidylinositol 3- Kinase/Akt1 Survival Pathway to Protect Oligodendrocytes from Tumor Necrosis Factor $\alpha$-Induced Apoptosis
}

\author{
Sai Latha Shankar, ${ }^{1}$ Kathleen 0'Guin, ${ }^{1}$ Mimi Kim, ${ }^{2}$ Brian Varnum, ${ }^{3}$ Greg Lemke, ${ }^{4}$ Celia F. Brosnan, ${ }^{1}$ and \\ Bridget Shafit-Zagardo ${ }^{1}$ \\ Departments of ${ }^{1}$ Pathology and ${ }^{2}$ Epidemiology, Albert Einstein College of Medicine, Bronx, New York 10461, ${ }^{3}$ Amgen Corporation, Thousand Oaks, \\ California 91320, and ${ }^{4}$ Molecular Neurobiology Laboratory, The Salk Institute, La Jolla, California 92037
}

Growth arrest-specific protein 6 (gas6) activity is mediated through the receptor tyrosine kinase family members Axl, Rse, and Mer, all of which are expressed in human oligodendrocytes. In this study, we examined whether recombinant human (rh) gas6 protects oligodendrocytes from growth factor (insulin) withdrawal or tumor necrosis factor- $\alpha$ (TNF $\alpha$ ) cytotoxicity. In addition, we examined whether the effect was caspase-dependent, which receptor mediated the protective effect, and whether survival required Akt1 activation. Oligodendrocyte viability was assessed by 04 staining and terminal deoxynucleotidyl transferase-mediated biotinylated UTP nick end labeling. Addition of rhgas 6 to insulin-depleted cultures resulted in a significant increase in oligodendrocyte viability. Rhgas 6 and caspase inhibitors also reduced active caspase- 3 immunoreactivity relative to TNF $\alpha$-only-treated cultures. In cultures treated with TNF $\alpha$ (100 $\mathrm{ng} / \mathrm{ml}$ ), the oligodendrocyte survival rate was $18 \%$ compared with cultures treated with TNF $\alpha$ and rhgas 6 (64\%) or the caspase inhibitors IETD-fmk [z-Ile-Glu(OMe)-Thr-Asp(OMe)-fluoromethyl ketone $] \quad(65 \%)$ and zVAD-fmk ( $\mathrm{N}$-benzyloxycarbonyl-Val-Ala-Aspfluoromethyl ketone) (63\%). Increased phosphoAkt (Ser473) immunoreactivity was detected 15 min after administration of gas6 and TNF $\alpha$ to oligodendrocyte cultures but not in TNF $\alpha$-treated cultures. The gas6 protective effect was abrogated by the Axl decoy receptor Axl-Fc, by the phosphatidylinositol 3 (PI3) kinase inhibitor LY294002 [2-(4-morpholinyl)-8-phenyl-1(4H)-benzopyran-4-one], and in $A k t 1^{-/-}$oligodendrocytes. Oligodendrocyte cultures established from wild-type and $R s e^{-/-}$mice, but not from $A x l^{-/-}$mice, were also protected from TNF $\alpha$-induced cell death when maintained in rhgas6. We conclude that gas6 signaling through the Axl receptor and the PI3 kinase/Akt1 survival pathway protects oligodendrocytes from growth factor withdrawal and TNF $\alpha$-mediated cell death.

Key words: Gas6; oligodendrocytes; TNF $\alpha$; apoptosis; Axl; Akt

\section{Introduction}

Axl, Mer, and Rse comprise a receptor tyrosine kinase family that is activated by growth arrest-specific protein 6 (gas6). These cell adhesion molecule-related receptors contain two Ig-like repeats and two fibronectin repeats in the extracellular domain, a kinase domain, and a cytoplasmic domain that, after autophosphorylation, can recruit signaling molecules (Kazlauskas, 1994; Stitt et al., 1995; Varnum et al., 1995; Ling et al., 1996; Braunger et al., 1997; Hasanbasic et al., 2004). gas6 is secreted by neurons and endothelial cells and is widely expressed in the CNS, suggesting that the interaction between gas6 and its receptors has physiological relevance ( $\mathrm{Li}$ et al., 1996; Prieto et al., 2000). The affinity of gas6 for the receptors is Axl $>$ Rse $>$ Mer with Axl activated by gas6 in the low nanomolar range (Nagata et al., 1996). In situ hybridization studies performed in rat CNS demonstrated that

Received Jan. 12, 2005; revised April 11, 2006; accepted April 13, 2006.

This work was supported by National Multiple Sclerosis Society Grant RG3020 (B.S.-Z) and National Institutes of Health Grant NS11920 (C.F.B). We thank Dr. Brad Poulos, Einstein Human Fetal Tissue Repository, for material.

Correspondence should be addressed to Dr. Bridget Shafit-Zagardo, Department of Pathology, Forcheimmer 516, 1300 Morris Park Avenue, Albert Einstein College of Medicine, Bronx, NY 10461. E-mail: zagardo@aecom.yu.edu. DOI:10.1523/JNEUROSCI.5063-05.2006

Copyright $\odot 2006$ Society for Neuroscience $\quad$ 0270-6474/06/265638-11\$15.00/0
Axl, Mer, and Rse receptors are expressed in the white matter during myelination (Prieto et al., 2000). We determined by reverse transcription-PCR that oligodendrocytes isolated from human fetal spinal cord express all three receptors by 20 gestational weeks (gw). Furthermore, immunoblot analysis of brain and fetal spinal cord homogenates confirmed the presence of all three receptors and gas6, supporting a role in human and rodent development (Shankar et al., 2003).

Growth factor-mediated survival of mammalian cells often involves the activation of the phosphatidylinositol 3-kinase (PI3K) pathway (Jones et al., 1999) that can promote cell survival by activating the serine/threonine kinase Akt (Franke et al., 1997; Datta et al., 1999). Akt protects cells of the CNS against growth factor withdrawal and cytotoxic cytokines (Takano et al., 2000). Oligodendrocytes require the PI3K/Akt pathway for survival, and overexpression of constitutively active Akt, but not mitogenactivated protein kinase kinase, protected oligodendrocytes from various cellular stresses, including tumor necrosis factor- $\alpha$ (TNF $\alpha$ )-induced injury (Vemuri and McMorris, 1996; Takano et al., 2000). Previously, we demonstrated that gas6 protects human fetal oligodendrocytes from apoptotic cell death in the absence of trophic support and dramatically enhanced human oligodendro- 
cyte survival in vitro. The gas6 prosurvival effect was blocked by inhibitors of the PI3 kinase pathway but not the extracellular signal-regulated kinase pathway (Shankar et al., 2003).

In this study, we examined the effect of insulin withdrawal or the addition of the cytokine TNF $\alpha$ as initiators of oligodendrocyte injury. We also tested the hypothesis that recombinant human (rh) gas6 engagement of the Axl receptor activates the PI3 kinase/Akt prosurvival pathway protecting oligodendrocytes from $\mathrm{TNF} \alpha$-induced apoptosis. TNF $\alpha$ was studied because it is one of the major secreted cytokines associated with white matter injury in multiple sclerosis and periventricular leukomalacia (Bitsch et al., 2000; Rezaie and Dean, 2002). Thus, our goal was to determine whether gas6 would protect oligodendrocytes from TNF $\alpha$-induced damage and to identify the receptor (Axl, Rse, or Mer) and signaling pathways involved.

\section{Materials and Methods}

Human oligodendrocyte cultures. Human fetal spinal cord tissue was obtained from the Human Fetal Tissue Repository as approved by the Institutional Review Board of Albert Einstein College of Medicine and state and federal laws. Human oligodendrocyte cultures were generated from 21-23 gw spinal cords as described previously (Shankar et al., 2003). Cells $\left(5 \times 10^{4}\right)$ were plated on poly-L-lysine (Sigma, St. Louis, MO)-coated 24-well tissue culture wells or on $12 \mathrm{~mm}$ glass coverslips (Fisher Scientific, Hampton, NH). Oligodendrocyte cultures were grown for $5 \mathrm{~d}$ in a chemically defined (CD) medium consisting of DMEM, N2 supplement (5000 ng/ml insulin, $10 \mu \mathrm{g} / \mathrm{ml}$ transferrin, $5 \mathrm{ng} / \mathrm{ml}$ selenite, $16 \mu \mathrm{g} / \mathrm{ml}$ putrescine, and $6 \mathrm{ng} / \mathrm{ml}$ progesterone; Invitrogen, Carlsbad, CA), penicillin/streptomycin at $100 \mathrm{U} / \mathrm{ml}$ and $0.1 \mathrm{mg} / \mathrm{ml}$, respectively, $10 \mathrm{ng} / \mathrm{ml}$ platelet-derived growth factor (PDGF), and $5 \mathrm{ng} / \mathrm{ml}$ neurotrophin-3 (NT-3). CD medium was supplemented with $400 \mathrm{ng} / \mathrm{ml}$ (5.6 nM) rhgas6 (Amgen, Thousand Oaks, CA) and cultured at $37^{\circ} \mathrm{C}$ and $5 \% \mathrm{CO}_{2}$. The purity of cultures was determined by immunostaining cells with an $\mathrm{O} 4$ monoclonal antibody (Sommer and Schachner, 1981; Gard and Pfeiffer, 1989) or rabbit antiserum against $2^{\prime}, 3^{\prime}$-cyclic nucleotide $3^{\prime}$ phosphodiesterase (CNP) (Raible and McMorris, 1989), the astrocytespecific glial fibrillary acidic protein (GFAP), neuron-specific nuclear protein (NeuN) antibody, CD45 and CD11b and were determined to be $71 \% \mathrm{O}^{+}{ }^{+} \mathrm{CNP}^{+}$and $10 \% \mathrm{GFAP}^{+}$astrocytes. Cells were negative for NeuN and type III tubulin (neurons), CD45 and CD11b (microglia), and vimentin (early astrocytes and endothelial cells). Thus, the remaining $19 \%$ of the cells that could not be accounted for with the standard oligodendrocyte-specific markers were likely human glial or neuronal progenitor cells.

Primary mouse cortical oligodendrocyte cultures. All animal studies were approved by the Institutional Animal Care and Use Committee. Our Animal Welfare Assurance is on file with the Office of Laboratory Animal Welfare. Animals are maintained under barrier conditions in static microisolation cages. These colonies are tested quarterly and confirmed to be free of adventitious murine agents. Mice lacking the $\mathrm{Axl}\left(A x l^{-/-}\right)$or the Rse $\left(\mathrm{Rse}^{-1-}\right)$ receptor were obtained from the Lemke laboratory (Lu et al., 1999) and backcrossed to C57BL/6J wild-type (WT) mice more than five generations. $A k t^{+/-}$mice were obtained from The Jackson Laboratory (Bar Harbor, ME). Axl ${ }^{+/-}, R s e^{+/-}$, and $A k t^{+/-}$heterozygotes were mated to obtain $A x l^{-/-}, R s e^{-1-}$, and $A k t 1^{-1-}$ homozygotes and WT littermates. Oligodendrocyte cultures were established from postnatal day $1 \mathrm{WT}$, homozygous knock-out mice by a modification of previously established protocols (Knapp et al., 1987; Armstrong, 1998; Sperber and McMorris, 2001). Mice were decapitated, and the cerebral hemispheres were removed aseptically. The meninges were removed, and the cortices were dissected in a dish on ice containing $\mathrm{Ca}^{2+} / \mathrm{Mg}^{2+}$ free HBSS (Invitrogen). The minced tissue was incubated in prewarmed trypsin/EDTA solution (0.025\% trypsin and $0.1 \mathrm{~mm}$ EDTA; Sigma) and shaken at $110 \mathrm{rpm}$ on a Clay Adams nutator (Becton Dickinson, Parsippany, NJ) at $37^{\circ} \mathrm{C}$ for $20 \mathrm{~min}$. Trypsinization was terminated by adding a 1:1 volume of $25 \mu \mathrm{g} / \mathrm{ml}$ soybean meal trypsin inhibitor (Sigma) for $5 \mathrm{~min}$ at room temperature (RT). The tissue was spun at $1000 \mathrm{rpm}$ for $5 \mathrm{~min}$ at
RT and incubated in $80 \mu \mathrm{g} / \mathrm{ml}$ DNase in HBSS containing 3.9\% $\mathrm{MgSO}_{4}$ for $10 \mathrm{~min}$ at $37^{\circ} \mathrm{C}$ to digest extracellular DNA. The tissue solution was then mechanically triturated by pipetting up and down 15 times. The cell suspension was centrifuged at $1000 \mathrm{rpm}$ for $5 \mathrm{~min}$ at RT, and the cell pellet was resuspended in $15 \mathrm{ml}$ of DMEM containing 2\% fetal bovine serum. The suspended cells were transferred to a T75 flask and incubated overnight in a $5 \% \mathrm{CO}_{2}, 37^{\circ} \mathrm{C}$ incubator to allow adherent cells including microglia and type 1 astrocytes to attach to the dish. Subsequently, nonadherent cells were collected and filtered twice through a cell strainer (40 $\mu \mathrm{m}$ pore size; Falcon, Franklin Lakes, NJ) and centrifuged at $1000 \mathrm{rpm}$ for $5 \mathrm{~min}$ at RT. The pelleted oligodendrocytes were resuspended in a serum-free CD medium containing $10 \mathrm{ng} / \mathrm{ml}$ PDGF and $10 \mathrm{ng} / \mathrm{ml}$ basic fibroblast growth factor (bFGF). The $5 \times 10^{4}$ cells were plated on polyL-lysine (Sigma)-coated 24-well tissue culture wells for the assessment of oligodendrocyte survival after treatments in the presence or absence of rhgas6 or on poly-L-lysine-coated coverslips (Fisher Scientific) for fluorescence microscopy. Cells were cultured at $37^{\circ} \mathrm{C}$ and $5 \% \mathrm{CO}_{2}$. To allow for the differentiation of the oligodendrocyte progenitor cells, $3 \mathrm{~d}$ after plating, bFGF was excluded from the PDGF-supplemented CD medium and replaced with $5 \mathrm{ng} / \mathrm{ml} \mathrm{NT}-3$ for an additional period of $2 \mathrm{~d}$ before all experimentation. Immunocytochemistry performed on day 7 mouse oligodendrocyte cultures indicated that $77 \%$ of the cells were $\mathrm{O}^{+}{ }^{+} \mathrm{CNP}^{+}$ oligodendrocytes, $22 \%$ were $\mathrm{GFAP}^{+}$astrocytes, and $<1 \%$ were $\mathrm{CD} 45$ and $\mathrm{CD} 11 \mathrm{~b}^{+}$microglia. No NeuN ${ }^{+}$neurons were detected. All subsequent treatments were performed on differentiated murine oligodendrocytes that were $\mathrm{O}_{4}^{+}$and $\mathrm{CNP}^{+}$.

Immunocytochemistry. Oligodendrocytes were plated in CD medium at $5 \times 10^{4}$ cells per well on poly-L-lysine-coated 24-well tissue culture plates or coverslips. To identify the expression of $\mathrm{O} 4$ and TNF receptor 1 (TNFR1) on human oligodendrocytes, immunocytochemistry was performed on day 7 murine oligodendrocytes. After treatments, oligodendrocyte cultures were fixed in prewarmed $4 \%$ paraformaldehyde for 30 min. Cultures were permeabilized with $0.25 \%$ Triton X-100 in $1 \times$ Trisbuffered saline [ $1 \times$ TBS $(0.14 \mathrm{M} \mathrm{NaCl}, 0.001 \mathrm{~m}$ Tris, $\mathrm{pH}$ 7.4)] for $30 \mathrm{~min}$, blocked in $10 \%$ goat serum in $5 \%$ nonfat dry milk or bovine serum albumin (BSA)/ $1 \times$ TBS for $1 \mathrm{~h}$, and incubated in the primary antibodies overnight in a humid chamber at $4^{\circ} \mathrm{C}$. The $0.25 \%$ Triton $\mathrm{X}-100$ permeabilization step was excluded for the immunostaining of the cell surface markers O4 and TNFR1. The O4 antibody (Bansal et al., 1989) was routinely used at 1:25 and CNP antibody (Raible and McMorris, 1989) at 1:500. The TNFR1 antibody (Austral Biologicals, San Ramon, CA) was used at 1:100. Cleaved caspase-3 (Asp175) rabbit polyclonal antibody (Cell Signaling Technology, Beverly, MA), an antibody that detects endogenous levels of the large fragment $(17 \mathrm{kDa})$ of activated caspase- 3 resulting from cleavage adjacent to aspartic acid 175 was used at 1:300. After three $1 \times$ TBS washes, 5 min each, the cells were incubated for $1 \mathrm{~h}$ at $\mathrm{RT}$ in the corresponding secondary antibodies conjugated to Alexa dyes (rabbit anti-mouse IgM or goat anti-rabbit IgG; Invitrogen), diluted 1:500 in 5\% nonfat dry milk/ $1 \times$ TBS. Coverslips were mounted on slides with Aquamount (Biomeda, Foster City, CA) and examined with a Leica AOBS laser scanning confocal microscope (Leica Microsystems, Bannockburn, IL).

TNF $\alpha$ treatment of oligodendrocyte cultures. Oligodendrocyte cultures were treated with $100 \mathrm{ng} / \mathrm{ml}$ recombinant human or mouse TNF $\alpha$ (PeproTech, Rocky Hill, NJ) in the absence or presence of $400 \mathrm{ng} / \mathrm{ml}$ rhgas6. Soluble Axl-Fc $(10 \mu \mathrm{g} / \mathrm{ml})$ was used as a decoy to block the rhgas6 effect; TrkA-Fc $(10 \mu \mathrm{g} / \mathrm{ml})$ was used as a negative control (Stitt et al., 1995). The cell-permeable pan-caspase inhibitor zVAD-fmk ( $N$-benzyloxycarbonylVal-Ala-Asp-fluoromethyl ketone) and the caspase-8 inhibitor IETDfmk [z-Ile-Glu(OMe)-Thr-Asp(OMe)-fluoromethyl ketone] (Calbiochem, La Jolla, CA) were used at $20 \mu \mathrm{m}$. The caspase inhibitors and TNF $\alpha$ were added simultaneously.

For the insulin withdrawal experiments, human or mouse oligodendrocytes were grown for 5 or $7 \mathrm{~d}$ in CD medium. On day 5 or 7 , cells were washed twice in HBSS and incubated with CD medium containing varying concentrations of insulin (25-5000 ng/ml), $10 \mathrm{ng} / \mathrm{ml} \mathrm{PDGF}$, and 5 $\mathrm{ng} / \mathrm{ml} \mathrm{NT}-3$ in the absence or presence of $400 \mathrm{ng} / \mathrm{ml}$ rhgas6; oligodendrocyte survival was determined $48 \mathrm{~h}$ later.

Terminal deoxynucleotidyl transferase-mediated biotinylated UTP nick 
end labeling assay and the assessment of oligodendrocyte cell survival. To assess apoptotic cell death in the TNF $\alpha$-treated oligodendrocytes incubated in the presence and absence of rhgas 6 terminal deoxynucleotidyl transferase-mediated biotinylated UTP nick end labeling (TUNEL), staining was performed using the Fluorescein In Situ Cell Death Detection kit (Roche Molecular Biochemicals, Indianapolis, IN). The TUNEL reaction preferentially labels cleaved genomic DNA generated during apoptosis by the addition of fluorescein dUTP at strand breaks. At $48 \mathrm{~h}$ after treatment, oligodendrocytes were fixed and permeabilized as described above for immunocytochemistry. $\mathrm{O} 4$ immunostaining was performed first, washed, and subsequently incubated in the TUNEL reaction mixture, prepared according to the recommendations manufacturer, for $1 \mathrm{~h}$ at $37^{\circ} \mathrm{C}$. Omission of the terminal deoxynucleotidyl transferase in the label solution served as a negative control. Cells were examined with an Olympus Optical (Melville, NY) IX70 inverted microscope. For each treatment, 20 random, $200 \times$ magnification microscopic fields consisting of $\sim 400-450$ cells in total were examined in duplicate wells of 24-well tissue culture plates. $\mathrm{O}^{+}{ }^{+} \mathrm{TUNEL}^{+}$nuclei were expressed as a percentage of the total number of $\mathrm{O}^{+}$cells per individual field [\% oligodendrocyte survival $=100-\%\left(\mathrm{O}^{+}{ }^{+} \mathrm{TUNEL}^{+} /\right.$total O$\left.\left.^{+}\right)\right]$.

Western blot analysis. Total protein homogenates were prepared from whole mouse brains at postnatal day 30 or for time course experiments at postnatal day $10-160$, analyzed by SDS-PAGE on $10 \%$ gels, and electrophoretically transferred to nitrocellulose, blocked with 5\% nonfat dry milk in $1 \times$ TBS (Shankar et al., 2003). Blots were incubated overnight at $4^{\circ} \mathrm{C}$ with affinity-purified rabbit polyclonal antibodies generated against Axl (Amgen) or Gas6 (Amgen). Visualization was by enhanced chemiluminescence (ECL) (Amersham Biosciences, Arlington Heights, IL).

O4/phosphoAkt (Ser473) double-label immunofluorescence microscopy of oligodendrocyte cultures and fluorescence intensity measurements. Human or mouse oligodendrocyte cultures were grown for $5 \mathrm{~d}$ on poly-Llysine-coated coverslips as described above. By day 5 in culture, the oligodendrocytes exhibited morphological and antigenic differentiation $\left(\mathrm{O}^{+}{ }^{+} \mathrm{CNP}^{+}\right)$. Cultures were washed and placed overnight in DMEM only without any trophic support. The following day, cultures were washed with HBSS and incubated in $100 \mathrm{ng} / \mathrm{ml} \mathrm{TNF} \alpha$ in DMEM (without insulin, PDGF, or NT-3) in the absence or presence of rhgas6 (400 $\mathrm{ng} / \mathrm{ml}$ ) for $15 \mathrm{~min}$. Cells were fixed and blocked with $10 \%$ goat serum in $5 \%$ nonfat dry milk and incubated with the $\mathrm{O} 4$ monoclonal antibody (1:25) overnight at $4^{\circ} \mathrm{C}$, washed three times in $1 \times$ TBS, and incubated with biotinylated anti-mouse IgM secondary antibody (1:200), followed by streptavidin Alexa 568. The secondary antibody and streptavidin Alexa 568 were diluted in $5 \%$ nonfat dry milk/ $1 \times$ TBS, and each incubation was performed for $1 \mathrm{~h}$ at RT. After O4 labeling, cells were permeabilized with $0.25 \%$ Triton X-100 in $1 \times$ TBS for 30 min at RT, blocked with $10 \%$ goat serum in $5 \%$ BSA, and incubated with anti-phosphoAkt1/PKB $\alpha$ (Ser473), clone 11E6 antibody (1:200 dilution in 5\% BSA/1 $\times$ TBS; Upstate Biotechnology, Lake Placid, NY) overnight at $4^{\circ} \mathrm{C}$. Cells were washed three times and incubated with anti-mouse $\operatorname{IgG}_{1}$ Alexa $488 \mathrm{sec}$ ondary antibody (1:500) for $1 \mathrm{~h}$ at RT. Coverslips were mounted with Aquamount (Biomeda). Images of random fields of $\mathrm{O} 4$ and phosphoAkt Ser473 immunostaining were collected using a Leica AOBS laser scanning confocal microscope at $600 \times$ magnification. Controls included complete labeling of either $\mathrm{O} 4$ or phosphoAkt antibody, followed by the secondary antibody of the second label and revealed no cross-reactivity. To ensure no crosstalk from one fluorescent channel to another, each channel was collected in the lambda scanning sequential mode with independent excitation and emission detection through its own narrow band filter.

To quantitate the phosphoAkt Ser473 immunofluorescence, lowmagnification photomicrographs were obtained with an Olympus Optical 1 X70 with a $20 \times, 1.0$ numerical aperture planapo optics inverted microscope with a Photometrics (Roper Scientific, Tuscon, AZ) Censys cooled CCD camera; images were collected on a personal computer using IP Lab Spectrum software (Scanalytics, Fairfax, VA). Immunofluorescence measurements for phosphoAkt Ser473 and O4 were obtained from $\sim 80$ cells in 15 random $200 \times$ magnification microscopic fields by NIH ImageJ software. phosphoAkt Ser473/O4 immunofluorescence quantification data were expressed as relative fluorescence intensity \pm SD. Con-
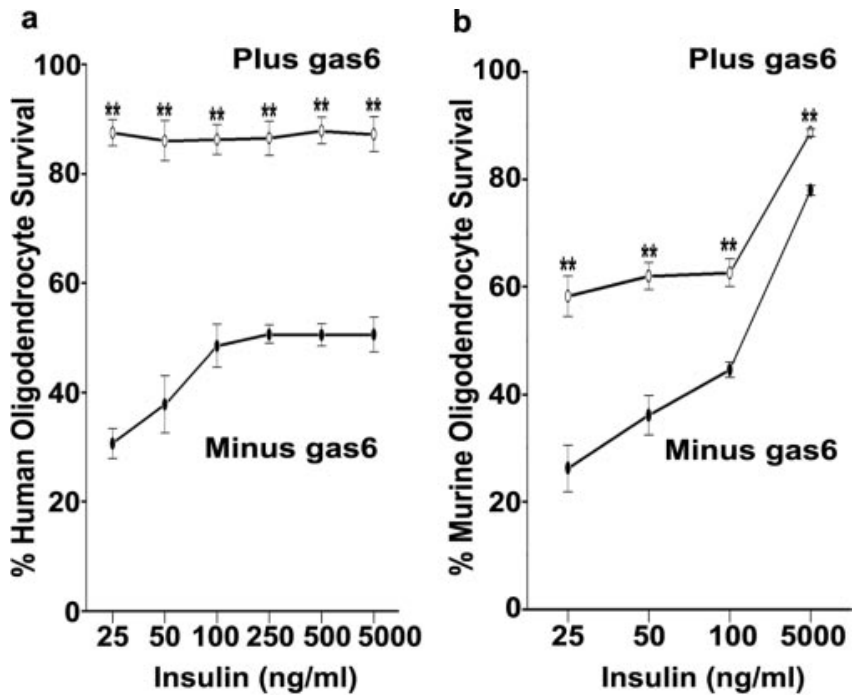

Figure 1. rhgas6 protects human and murine oligodendrocytes from insulin withdrawal induced-apoptosis. Human fetal oligodendrocytes $(\boldsymbol{a})$ or murine oligodendrocytes $(\boldsymbol{b})$ were grown in CD medium supplemented with insulin, PDGF, NT-3, with rhgas6 (a) or without rhgas6 (b) for $5 \mathrm{~d}$ on poly---lysine-coated plastic tissue culture wells in duplicate. On day 5 in culture, cells were washed twice and incubated in CD medium containing PDGF, NT-3, and the absence (Minus) or presence (Plus) of rhgas $6(400 \mathrm{ng} / \mathrm{ml} ; 5.6 \mathrm{~nm})$ with varying concentrations of insulin ( $25-5000 \mathrm{ng} / \mathrm{ml}$ ) for $48 \mathrm{~h}$. Apoptotic oligodendrocytes were detected by immunofluorescence staining with the oligodendrocyte-specific 04 antibody, followed by TUNEL staining. The number of $04{ }^{+}$TUNEL $^{+}$double-labeled oligodendrocytes was counted from duplicate wells in 20 random, $200 \times$ microscopic fields and expressed as a percentage of the total $04{ }^{+}$cell numbers per field. Representative data are shown as percentage oligodendrocyte survival (mean \pm SD) with $\sim 40004^{+}$cells counted per treatment condition; three independent experiments were performed with similar results. ANOVA results indicated a significant effect of rhgas 6 treatment $\left({ }^{* *} p<0.0001\right)$.

firmation of data were obtained by repeating the experiment three times on independent material.

PI3 kinase/Akt inhibition using LY294002. Human oligodendrocyte cultures grown for $5 \mathrm{~d}$ in $\mathrm{CD}$ medium in the presence of rhgas6 were incubated with $100 \mathrm{ng} / \mathrm{ml} \mathrm{TNF} \alpha$ for $48 \mathrm{~h}$ in the presence or absence of the PI3 kinase inhibitor LY294002 [2-(4-morpholinyl)-8-phenyl-1(4H)benzopyran-4-one] (10 $\mu \mathrm{m}$; Promega, Madison, WI). After $48 \mathrm{~h}$, oligodendrocytes were fixed and immunofluorescence staining for $\mathrm{O} 4$ was performed followed by TUNEL staining. For each treatment, 20 random, $200 \times$ magnification fields consisting of $\sim 400$ cells were examined in duplicate wells of 24 -well tissue culture plates, and the percentage oligodendrocyte survival was determined.

Data analysis. Data from each of the random microscopic fields, which were examined for $\mathrm{O}^{+}{ }^{+} \mathrm{TUNEL}^{+}$oligodendrocytes, were analyzed as independent observations in an ANOVA model using Prism 2.01 software (GraphPad Software, San Diego, CA) to evaluate the effect of treatment. To validly combine data from multiple experiments in the analysis, the ANOVA model also included a factor to control for experiment to experiment variability, in addition to the main effect for treatment. Therefore, all $p$ values corresponding to the effect of treatment are adjusted for between-experiment effects. Data are expressed as mean $\pm \mathrm{SD}$.

\section{Results}

\section{rhgas 6 is a survival factor for human oligodendrocytes after} insulin withdrawal

The addition of rhgas6 to $\mathrm{CD}$ medium containing insulin at a final concentration of $5000 \mathrm{ng} / \mathrm{ml}$ significantly enhanced the survival of cultured human oligodendrocytes and reduced the number of TUNEL ${ }^{+}$oligodendrocytes relative to CD medium lacking rhgas6 (Shankar et al., 2003). Here, we tested whether rhgas6 would maintain oligodendrocyte survival in CD medium with reduced insulin. Human (Fig. 1a) or mouse (Fig. 1b) oligoden- 
drocytes were washed twice in HBSS and incubated with CD medium containing rhgas 6 and varying concentrations of insulin (25-5000 ng/ml). Oligodendrocyte survival was determined $48 \mathrm{~h}$ later and compared with cultures similarly maintained in the absence of rhgas6. As demonstrated in Figure 1, $a$ and $b$, the presence of rhgas6 in the medium (open circles) protected against insulin withdrawal with $>60-75 \%$ oligodendrocyte survival observed in the cultures with lower insulin concentrations (25-100 $\mathrm{ng} / \mathrm{ml})$ for $48 \mathrm{~h}$. When compared with the cultures grown in CD medium in the absence of rhgas6 (filled circles), rhgas6 significantly increased oligodendrocyte survival over the entire range of insulin concentrations examined. In the absence of rhgas6, oligodendrocyte survival was dramatically reduced in cultures with $<100 \mathrm{ng} / \mathrm{ml}$ insulin in the medium. These data demonstrate that rhgas 6 exerts its antiapoptotic effects independent of insulin-activated IGF-1 receptor (IGF1R) and that rhgas6 significantly enhances oligodendrocyte survival over that induced by PDGF, NT-3, and low insulin concentrations.

\section{Variation in the concentration of rhgas 6 and TNF $\alpha$ alters oligodendrocyte survival}

We next examined whether rhgas6 would protect human oligodendrocytes against cell death induced by the cytotoxic cytokine TNF $\alpha$. As illustrated in Figure 2, $a$ and $b$, we observed numerous $\mathrm{O}{ }^{+} \mathrm{TUNEL}^{+}$apoptotic oligodendrocytes $48 \mathrm{~h}$ after the addition of $100 \mathrm{ng} / \mathrm{ml} \mathrm{TNF} \alpha$. In contrast, the coadministration of 100 $\mathrm{ng} / \mathrm{ml} \mathrm{TNF} \alpha$ and $400 \mathrm{ng} / \mathrm{ml}$ rhgas6 significantly reduced the numbers of apoptotic oligodendrocytes (Fig. 2c). As shown in Figure $2 d$, addition of varying doses of TNF $\alpha(10-100 \mathrm{ng} / \mathrm{ml})$ induced apoptosis in a concentration-dependent manner. In the absence of rhgas 6 and in the presence of $100 \mathrm{ng} / \mathrm{ml} \mathrm{TNF} \alpha, 18.7 \pm$ $4.4 \%$ oligodendrocytes survived, whereas the addition of 400 $\mathrm{ng} / \mathrm{ml}$ rhgas6 led to a dramatic increase in cell survival to $64.3 \pm$ $6.1 \%$. Whereas the addition of varying concentrations of TNF $\alpha$ induced a dose-dependent decrease in oligodendrocyte survival, the coadministration of $10-100 \mathrm{ng} / \mathrm{ml} \mathrm{TNF} \alpha$ with rhgas6 significantly protected against oligodendrocyte apoptosis relative to TNF $\alpha$ alone.

We examined whether varying concentrations of rhgas6 (25$400 \mathrm{ng} / \mathrm{ml} ; 0.35-5.6 \mathrm{nM}$ ) would protect human oligodendrocytes from cell death $48 \mathrm{~h}$ after the administration of TNF $\alpha$ (100 ng/ $\mathrm{ml}$ ). As shown in Figure $2 e$ (open bar), in the absence of rhgas6, $40.7 \pm 6.0 \%$ of the oligodendrocytes survived. After administration of TNF $\alpha$ (black bar), there was an additional $\sim 20 \%$ reduction in oligodendrocyte survival $(20.2 \pm 5.3 \%)$ after $48 \mathrm{~h}$. Addition of 25-400 ng/ml rhgas6 significantly increased oligodendrocyte survival at all doses in both the absence of TNF $\alpha$ (white bar with black dots) and the presence of TNF $\alpha$ (black bar with white dots). Approximately $35 \%$ of the oligodendrocytes survived TNF $\alpha$ cytotoxicity in rhgas 6 concentrations of 25 and 50 $\mathrm{ng} / \mathrm{ml}$. When $100-400 \mathrm{ng} / \mathrm{ml}$ rhgas 6 was added to the medium, $52-74 \%$ of the oligodendrocytes survived TNF $\alpha$ toxicity, demonstrating that rhgas 6 protected human oligodendrocytes from $\mathrm{TNF} \alpha$-induced apoptosis in a concentration-dependent manner.

The specificity of the rhgas 6 protective response from TNF $\alpha$ induced apoptosis was examined by simultaneously administering TNF $\alpha$ and rhgas6 with the Axl decoy receptor Axl-Fc or a control decoy receptor TrkA-Fc. The Axl-Fc binds rhgas6 and, therefore, is a control to demonstrate that rhgas 6 activity is a direct response. Figure $2 f$ demonstrates that the addition of Axl-Fc eliminated the rhgas6-induced survival effect to oligodendrocytes in both the presence of rhgas 6 alone and the presence of rhgas 6 and $\operatorname{TNF} \alpha$. The percentage oligodendrocyte survival in the presence of the Axl-Fc was equivalent to the percentage survival observed after TNF $\alpha$ treatment in the absence of rhgas6. TrkA-Fc did not alter the rhags6 response, indicating that rhgas6 significantly protects oligodendrocytes from TNF $\alpha$ cytotoxicity.

Because TNF $\alpha$-mediated apoptosis in oligodendrocytes is a result of TNF $\alpha$ binding to the TNFR1 (Hsu et al., 1996), we confirmed that the receptor was expressed on $\mathrm{O} 4{ }^{+}$oligodendrocytes that were grown for $6 \mathrm{~d}$ in CD medium. As shown in Figure $2 g$, the $\mathrm{O}^{+}{ }^{+}$oligodendrocytes (red) express the TNFR1 (green). TNFR1 membrane expression was primarily seen on the $\mathrm{O}^{+}$cell surface with fainter staining on the processes; robust $\mathrm{O} 4 \mathrm{immu}-$ noreactivity was observed on both the oligodendrocyte cell body and the processes.

\section{TNF $\alpha$-induced caspase activation is inhibited by the addition of rhgas 6}

Figure $3 a$ demonstrates that, $48 \mathrm{~h}$ after the addition of $100 \mathrm{ng} / \mathrm{ml}$ $\mathrm{TNF} \alpha$, there is an increase in active caspase-3 (green) detected within the $\mathrm{O}^{+}{ }^{+}$(red) oligodendrocyte cultures. Quantification of the data showed that $68 \%$ of the oligodendrocytes were $\mathrm{O}^{+} /$ cleaved caspase $-3^{+}$(Fig. 3c). In contrast, cultures treated with rhgas6 and TNF $\alpha$ for the identical period of time had significantly fewer active caspase- $3^{+}$cells (Fig. $3 b$ ). Addition of rhgas 6 and TNF $\alpha$ to the medium significantly decreased the numbers of $\mathrm{O}_{4}{ }^{+}$oligodendrocytes with active caspase- 3 to $43 \%$ (Fig. 3 c). To determine whether the inhibition of caspases would enhance oligodendrocyte survival as effectively as rhgas6, day 5 human oligodendrocytes were washed twice and incubated in CD medium minus rhgas6 (Fig. 3d, open bar) plus $20 \mu \mathrm{M} \mathrm{zVAD-fmk} \mathrm{(stripes),}$ IETD-fmk (diagonal), or rhgas6 (dots) and examined $48 \mathrm{~h}$ later. In the absence of TNF $\alpha$, rhgas6 was most effective at supporting oligodendrocyte cell viability. In the presence of TNF $\alpha$, rhgas6 was as effective as the caspase inhibitors in protecting the cultures from TNF $\alpha$ cytotoxicity. These results demonstrate that TNF $\alpha$ induces caspase- 8 and downstream caspase activation in human fetal oligodendrocytes and that rhgas 6 and caspase inhibitors can reduce $\mathrm{TUNEL}^{+}$nuclei resulting from $\mathrm{TNF} \alpha$-induced cytotoxicity. These experiments not only show that caspase inhibitors can block TNF $\alpha$-induced oligodendrocyte cytotoxicity but also stress the ability of rhgas 6 to inhibit TNF $\alpha$-induced caspase activation as effectively as the chemical caspase inhibitors.

\section{Rhgas6 protects human oligodendrocytes from cell death via the PI3 kinase/Akt pathway}

To determine whether rhgas6 signaling protects against TNF $\alpha$ induced toxicity via the PI3 kinase/Akt pathway, we examined whether the addition of TNF $\alpha$ alone or rhgas 6 and TNF $\alpha$ would activate and hence phosphorylate the prosurvival kinase Akt. Human oligodendrocytes were placed overnight in DMEM, washed, treated with TNF $\alpha$ plus and minus rhgas 6 for $15 \mathrm{~min}$, and immediately fixed with $4 \%$ paraformaldehyde. Double-label immunofluorescence was performed with $\mathrm{O} 4$ and a phosphoAkt Ser473 antibody (Fig. 4a), and the relative phosphoAkt Ser473/O4 fluorescence intensity was compared with DMEM-only-treated cells arbitrarily set as 1.0 (Fig. $4 b$ ). TNF $\alpha$ alone did not significantly activate phosphoAkt. However, the presence of rhgas 6 in the $\mathrm{TNF} \alpha$-treated cultures activated Akt relative to TNF $\alpha$ alone (Fig. $4 b)$. When the PI3 kinase inhibitor LY294002 was simultaneously added to the medium with TNF $\alpha$ plus rhgas6, phosphoAkt immunoreactivity was reduced similar to the TNF $\alpha$-only-treated cultures (Fig. 4b). To address whether rhgas6-induced Akt activation is enhanced in the presence of other survival-promoting factors, oligodendrocyte cultures were treated with insulin, 
O4 / TUNEL
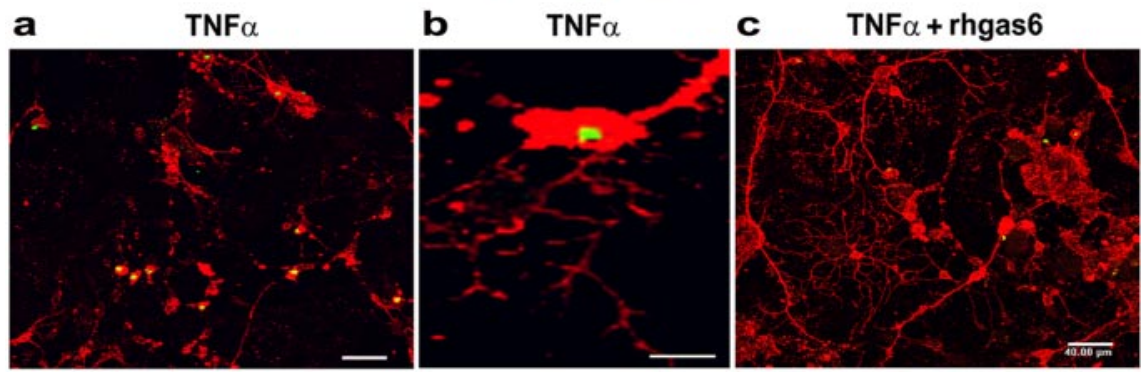

d

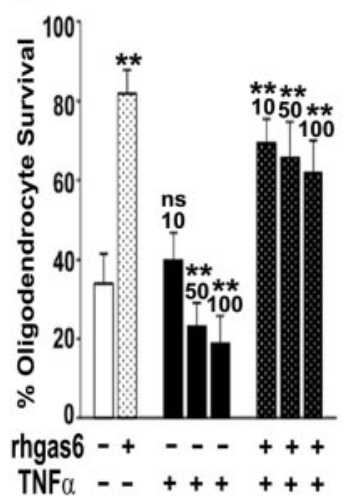

Treatments (48h)
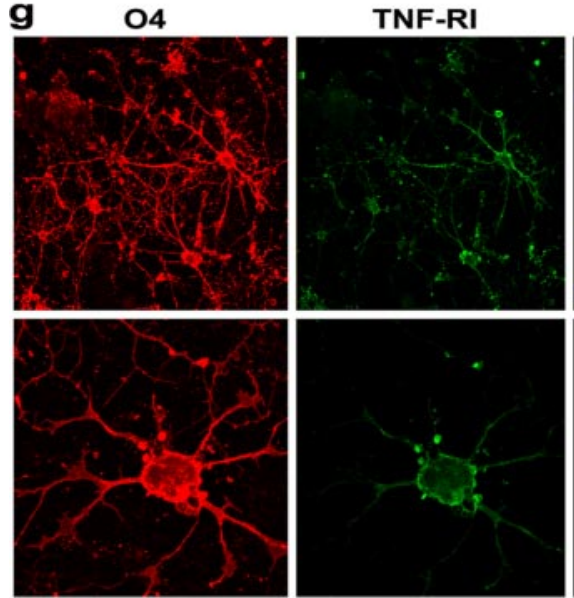
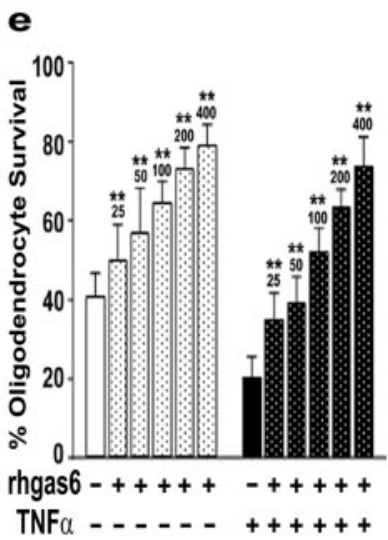

Treatments (48h) f

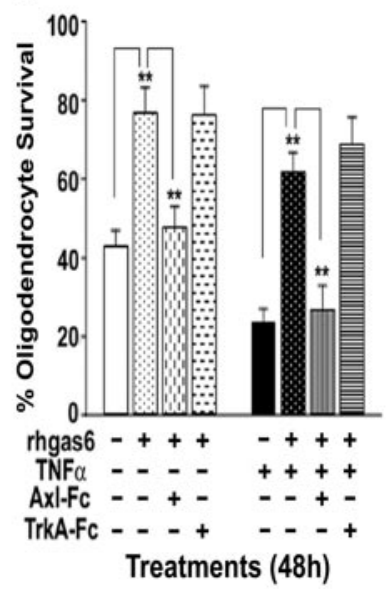

DAPI
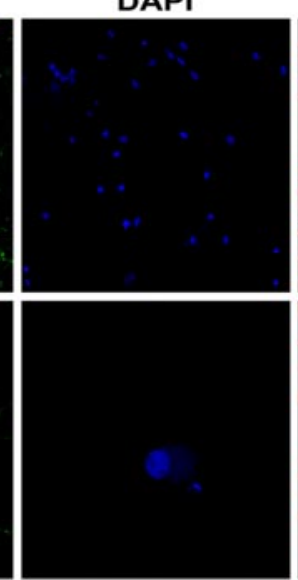

Merge
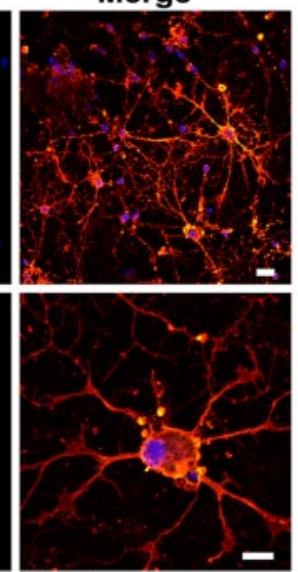

Figure 2. rhgas6 prevents dose-dependent TNF $\alpha$-induced oligodendrocyte apoptosis. Human fetal oligodendrocytes grown in CD medium plus rhgas 6 for $5 \mathrm{~d}$ were washed twice and incubated in CD medium containing $5000 \mathrm{ng} / \mathrm{ml}$ insulin in the absence of rhgas $6(\boldsymbol{a}, \boldsymbol{b})$ or the presence of rhgas $6(\boldsymbol{c})(400 \mathrm{ng} / \mathrm{ml})$ and $100 \mathrm{ng} / \mathrm{ml}$ human recombinant TNF $\alpha$ for $48 \mathrm{~h}$. Cells were fixed and immunostained with 04 (red), followed by TUNEL (green). A marked increase in $04{ }^{+}$TUNEL $^{+}$oligodendrocytes was observed in cultures incubated with TNF $\alpha$ in the absence of rhgas $6(\boldsymbol{a})$. $\boldsymbol{b}$ shows a representative $04^{+}{ }^{\text {TUNEL }}{ }^{+}$double-labeled oligodendrocyte at high magnification. Scale bars: $\boldsymbol{a}, \boldsymbol{c}, 40 \mu \mathrm{m} ; \boldsymbol{b}, 10 \mu \mathrm{m}$. $\boldsymbol{d}$, TNF $\alpha(10-100 \mathrm{ng} / \mathrm{ml})$ was administered in the absence or presence of rhgas6. The number of $04^{+}$TUNEL $^{+}$double-labeled oligodendrocytes was counted from duplicate wells in 20 random, $200 \times$ microscopic fields containing $\sim 350-40004^{+}$oligodendrocytes in total. Data are shown as percentage oligodendrocyte survival (mean \pm SD) of one of three independent experiments with similar results. ANOVA results indicated a significant effect on oligodendrocyte survival of TNF $\alpha$ alone or rhgas6 treatment alone or when rhgas 6 was administered with TNF $\alpha\left({ }^{* *} p<0.0001\right)$ when compared with minus gas 6 or TNF $\alpha$ alone. $e$, Human oligodendrocytes were grown in CD medium plus $400 \mathrm{ng} / \mathrm{ml}$ rhgas 6 for $5 \mathrm{~d}$ and washed with HBSS. Cultures were incubated for $48 \mathrm{~h}$ in CD medium containing $5000 \mathrm{ng} / \mathrm{ml}$ insulin with varying concentrations of rhgas $6(25-400 \mathrm{ng} / \mathrm{ml} ; 0.36-5.6 \mathrm{~nm})$ in the presence and absence of $100 \mathrm{ng} / \mathrm{ml}$ TNF $\alpha$. Cells were fixed and stained with the 04 antibody, followed by TUNEL labeling. The numbers of $04^{+} / \mathrm{TUNEL}^{+}$double-labeled oligodendrocytes were counted from 20 random, $200 \times$ microscopic fields from duplicate wells containing $\sim 50004^{+}$oligodendrocytes in total. Data are shown as percentage oligodendrocyte survival (mean \pm SD) obtained from one of two independent experiments with a second experiment yielding similar results. Significance relative to untreated or TNF $\alpha$ alone controls for all rhgas 6 and rhgas6 plus TNF $\alpha$ treatments was ${ }^{* *} p<0.0001$ (ANOVA). f, Axl-Fc but not the TrkA-Fc decoy receptor blocks the rhgas 6 protective effect. Human oligodendrocytes were grown as above and treated for $48 \mathrm{~h}$ with rhgas 6 ( $400 \mathrm{ng} / \mathrm{ml}), \mathrm{Axl}-\mathrm{Fc}(10$
IGF-1, PDGF $\alpha$, or NT-3 in the presence and absence of rhgas6. rhgas6-induced Akt activation was neither additive nor synergistic in the presence of any of the survivalpromoting factors (Fig. 4c).

To determine whether Akt activation was transient or sustained after rhgas6 stimulation, oligodendrocytes were placed overnight in DMEM only without any trophic support, washed with HBSS, and treated with DMEM plus rhgas6 for $5 \mathrm{~min}$, $15 \mathrm{~min}, 30 \mathrm{~min}, 1 \mathrm{~h}$, and $24 \mathrm{~h}$ time points. Relative phosphoAkt Ser473/O4 fluorescence intensities were obtained and compared with DMEM-only-treated cells. As shown in Figure $4 d$, a significant increase in relative phosphoAkt Ser473/O4 fluorescence intensity was observed 5 min after rhgas 6 treatment; the maximal increase in phosphoAkt Ser473/O4 was observed at 15 and 30 min after rhgas 6 treatment. By $1 \mathrm{~h}$, Akt activation was reduced, but elevated levels of phosphoAkt persisted at $24 \mathrm{~h}$. Thus, rhgas6 treatment of oligodendrocytes results in sustained Akt activation. We examined whether inhibiting the rhgas6-induced Akt activation with LY294002 would influence oligodendrocyte survival $48 \mathrm{~h}$ after treatment with TNF $\alpha$. Figure $4 e$ demonstrates that oligodendrocyte survival was compromised in the rhgas6 plus TNF $\alpha$-treated cultures after the addition of LY294002. Thus, the rhgas6-dependent increase in oligodendrocyte survival is dependent on the PI3 kinase/Akt pathway, and LY294002 eliminated the rhgas6-induced survival effect.

Rhgas6 protection against TNF $\alpha$ induced apoptosis is mediated through the Axl receptor

Immunoblot analysis of various developmental time points determined that Axl and gas 6 are expressed throughout rodent brain development. Both Axl and gas6 were expressed at high levels in whole mouse brain protein homogenates at post-

$\mu \mathrm{g} / \mathrm{ml})$, or TrkA-Fc $(10 \mu \mathrm{g} / \mathrm{ml})$ in the absence and presence of TNF $\alpha(100 \mathrm{ng} / \mathrm{ml})$. Data were obtained from 20 random, $200 \times$ microscopic fields from duplicate wells consisting of $\sim 50004^{+}$oligodendrocytes in total. Data are expressed as percentage oligodendrocyte survival (mean $\pm S D$ ) obtained from a single experiment $\left({ }^{* *} p<0.0001\right.$, unpaired Student's $t$ test; $n$ s, not significant; $p \geq 0.05$ ). $\boldsymbol{g}$, Expression of TNFR1 in primary cultures of human oligodendrocytes. Top, A representative low-magnification field of $04^{+}$(red) oligodendrocytes expressing TNFR1 (green). Nuclei were labeled with 4',6'-diamidino-2-phenylindole (DAPI) (blue). Scale bar, 10 $\mu \mathrm{m}$. Bottom, $04^{+}$oligodendrocyte with membrane expression of TNFR1 primarily at the cell surface with fainter staining in processes. Scale bar, $8 \mu \mathrm{m}$. 


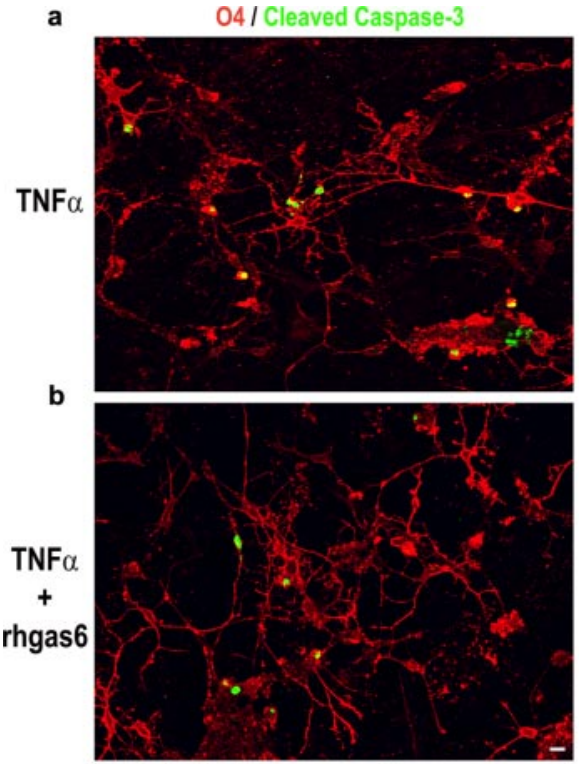

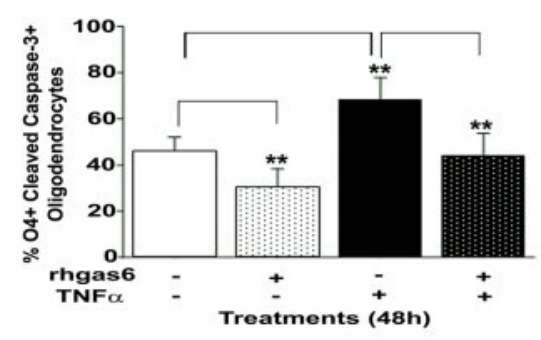

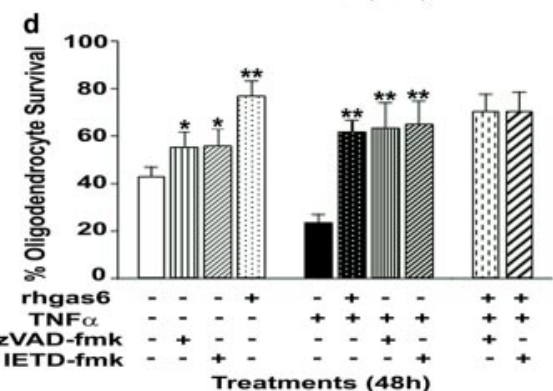

Figure 3. rhgas6 is as effective as the pan-caspase inhibitor ZVAD-fmk and the caspase-8 inhibitor IETD-fmk at protecting human oligodendrocytes against TNF $\alpha$-induced apoptosis. $\boldsymbol{a}$, TNF $\alpha$ treatment of human oligodendrocytes induces the activation of caspase-3. Human oligodendrocytes were grown in CD medium plus rhgas 6 for $5 \mathrm{~d}$, washed with HBSS, and incubated for $48 \mathrm{~h}$ in CD medium containing $5000 \mathrm{ng} / \mathrm{ml}$ insulin and TNF $\alpha(100 \mathrm{ng} / \mathrm{ml})$ in the absence $(\boldsymbol{a})$ and presence $(\boldsymbol{b})$ of rhgas $6(400 \mathrm{ng} / \mathrm{ml})$. Cells were fixed and immunostained with 04 antibody (red), followed by cleaved caspase-3 antibody (green). c, Quantitation of $04^{+} /$cleaved caspase- $3^{+}$oligodendrocytes after TNF $\alpha$ alone or with rhgas 6 treatment. $04^{+} /$cleaved caspase- $3^{+}$doublelabeled oligodendrocytes were counted from 20 random, $200 \times$ microscopic fields from duplicate wells containing $\sim 35004^{+}$ oligodendrocytes in total. Data are shown as percentage $04^{+} /$cleaved caspase $-3^{+}$oligodendrocytes (mean \pm SD) obtained from one of two independent experiments with a second experiment yielding similar results $\left({ }^{* *} p<0.0001\right.$, ANOVA). $\boldsymbol{d}$, Human oligodendrocyte cultures grown in rhgas 6 for $5 \mathrm{~d}$ were washed with HBSS and incubated for $48 \mathrm{~h}$ in TNF $\alpha(100 \mathrm{ng} / \mathrm{ml})$ in the presence or absence of rhgas $6(400 \mathrm{ng} / \mathrm{ml})$, with and without the cell-permeable pan-caspase inhibitor ZVAD-fmk or the caspase-8 inhibitor IETD-fmk (20 $\mu \mathrm{m})$. Apoptotic oligodendrocytes were detected by immunofluorescence staining with the 04 antibody, followed by TUNEL labeling. $04^{+} /$TUNEL $^{+}$double-labeled oligodendrocytes were counted from 20 random, $200 \times$ microscopic fields from duplicate wells containing $\sim 4004^{+}$oligodendrocytes in total. Data are shown as percentage oligodendrocyte survival (mean \pm SD) obtained from one of two independent experiments $\left({ }^{*} p<0.001,{ }^{* *} p<0.0001\right.$, ANOVA).

natal days 10-13 (Fig. 5a), and Axl remained high through day 30. Although gas6 and Axl levels decreased by day 60, protein levels were detectable in the adult mouse brain at day 160 .

To determine whether the loss of the Axl or the Rse receptor would compromise murine oligodendrocyte survival, $\mathrm{O}^{+}{ }^{+} \mathrm{CNP}^{+}$oligodendrocyte cultures (Fig. $5 b$ ) prepared from postnatal day 1 mouse brains were challenged with TNF $\alpha$ and rhgas6. In the absence of rhgas6, the percentage oligodendrocyte survival in the WT, $A x l^{-/-}$, and $\mathrm{Rse}^{-/-}$cultures was $>74 \%$ (Fig. $5 d$, white bars). When rhgas6 was administered to each of the cultures (stippled bars), there was a statistically significant increase in the percentage oligodendrocyte survival in the WT and $\mathrm{Rs}^{-{ }^{--}}$mice but not in the $A \mathrm{xl}^{-/-}$mice, suggesting that, in the presence of exogenous rhgas6, oligodendrocyte survival can be enhanced only when the Axl receptor is present. Furthermore, when $100 \mathrm{ng} / \mathrm{ml} \mathrm{TNF} \alpha$ was administered to the cultures in the absence of rhgas6 (black bars), there was a dramatic decrease in oligodendrocyte viability that could be recovered when rhgas 6 was administered to the WT and $R s e^{-/-}$cultures but not the $A x l^{-1-}$ cultures (Fig. $5 c$,d, black stippled bars). These results suggest that the presence of the Axl receptor is crucial for rhgas6-induced oligodendrocyte survival after TNF $\alpha$ administration.

To address whether rhgas6 protected murine oligodendrocytes from TNF $\alpha$-induced apoptosis independent of the survival induced by high insulin concentrations activating IGF1R, oligodendrocyte cultures were washed thrice to remove trophic factors, and the medium was replaced with CD medium containing
$100 \mathrm{ng} / \mathrm{ml}$ TNF $\alpha$ plus and minus 400 $\mathrm{ng} / \mathrm{ml}$ rhgas 6 and a range of insulin concentrations $(25-5000 \mathrm{ng} / \mathrm{ml})$. After $48 \mathrm{~h}$, the cultures were fixed and stained with O4 and TUNEL, and the percentage oligodendrocyte survival was quantified. When compared with TNF $\alpha$ alone, rhgas6 significantly increased oligodendrocyte survival at both high and low insulin concentrations (Fig. 5e). This demonstrated that rhgas6 could protect murine oligodendrocytes from $\mathrm{TNF} \alpha$ toxicity at reduced insulin concentrations (25-100 ng/ml).

Because gas6 signaling to Axl protects oligodendrocytes from $\mathrm{TNF} \alpha$-induced cell death, we examined whether rhgas6 would activate Akt in the $A x l^{-/-}$mice and whether rhgas6-treated oligodendrocytes from $A k t 1^{-/-}$mice would be protected from TNF $\alpha$-induced cell death. Murine oligodendrocytes were placed overnight in DMEM, washed, and simultaneously treated for $15 \mathrm{~min}$ in growth factor-free DMEM with TNF $\alpha$ plus or minus rhgas6. Cultures were fixed, double-label immunofluorescence was performed with $\mathrm{O} 4$ and the phosphoAkt serine 473 antibodies, and the relative phosphoAkt and $\mathrm{O} 4$ fluorescence intensities were quantified. Figure $6 a$ shows that, in the WT cultures, rhgas6 alone (white stippled bars) or rhgas6 plus TNF $\alpha$ (black stippled bars) induced an approximate threefold increase in phosphoAkt Ser473 relative to untreated cultures or cultures treated with $\mathrm{TNF} \alpha$ alone. However, in the $A x l^{-/-}$cultures, no increase in phosphoAkt was observed. To determine whether the $A x l^{-/-}$oligodendrocytes were capable of Akt phosphorylation in response to other survival-promoting factors, we treated $A x l^{-/-}$ cultures for $15 \mathrm{~min}$ in growth factor-free DMEM or medium containing rhgas6, IGF-1, NT-3, or PDGF. Whereas rhgas6 lacked the ability to induce Akt phosphorylation in $A x l^{-/-}$oligodendrocytes (Fig. 6b), a robust Akt activation was observed in cultures treated with IGF-1 (4.3-fold), NT-3 (4.2-fold), and PDGF (3.6-fold).

Akt1 is the predominant Akt isoform in oligodendrocytes. Therefore, we treated oligodendrocyte cultures prepared from $A k t 1^{-/-}$mouse brains with TNF $\alpha$ plus and minus rhgas 6 and examined whether rhgas 6 protected against TNF $\alpha$-induced cell death. Treatments were performed with $100 \mathrm{ng} / \mathrm{ml}$ insulin in the medium to determine whether the effect of rhgas6 on $A k t 1^{-/-}$ oligodendrocyte survival was independent of insulin-activated IGF1R. As shown in Figure $6 c$, treatment of the $A k t 1^{-/-}$cultures with rhgas6 (white stippled bars) or rhgas6 plus TNF $\alpha$ (black stippled bars) did not alter oligodendrocyte survival relative to the untreated cultures or cultures treated with only TNF $\alpha$. These results demonstrate that rhgas6/Axl signaling protects oligodendrocytes from TNF $\alpha$-induced apoptosis by activating the PI3 kinase/Akt1 signaling pathway.

\section{Discussion}

Our studies demonstrate that rhgas6 protects oligodendrocytes against growth factor withdrawal and TNF $\alpha$-induced cytotoxic- 
a Phospho-Akt
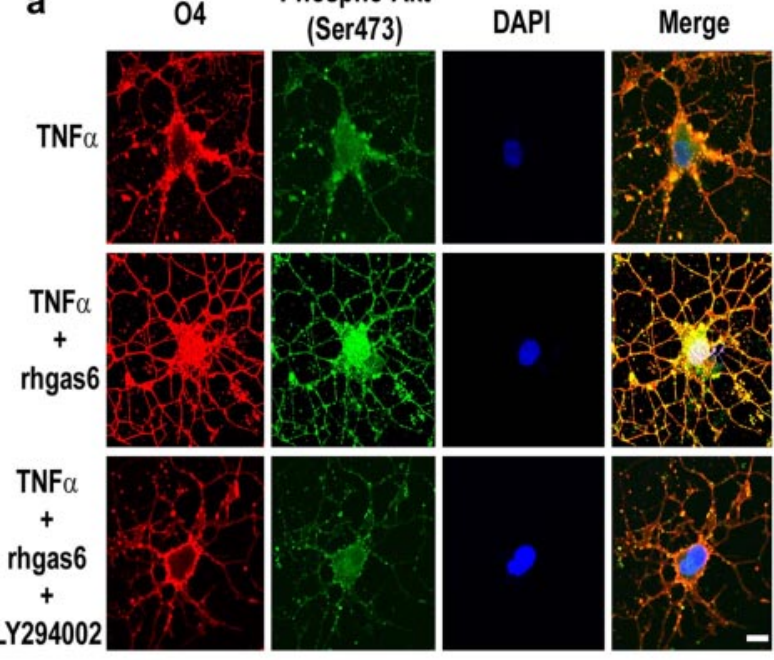

Low Magnification Field
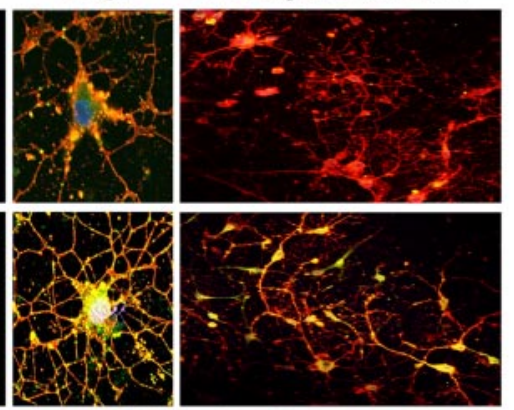

b

\section{c}
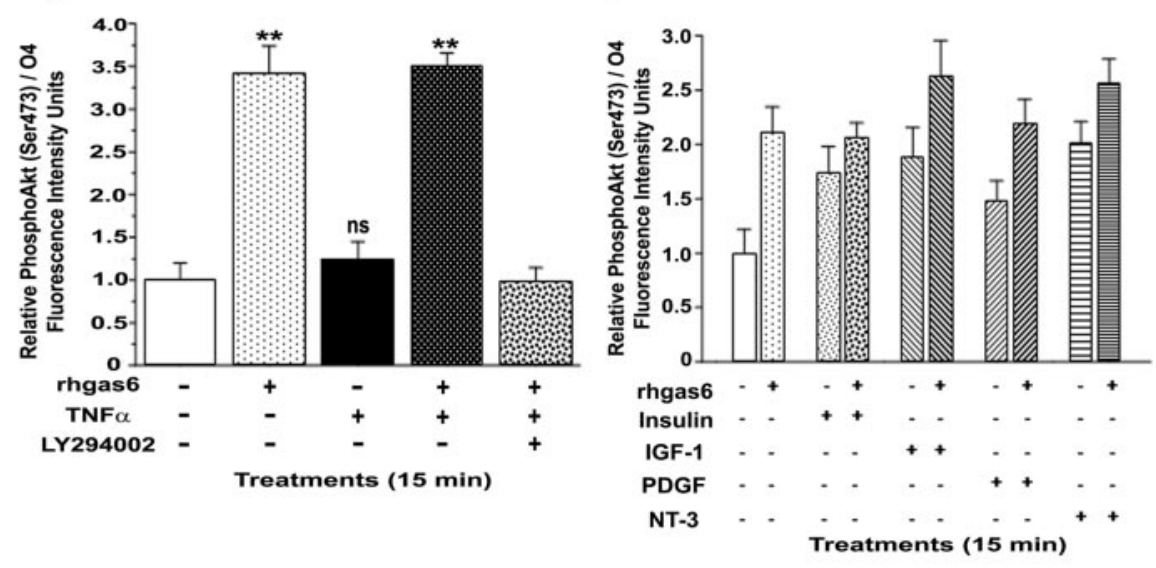

d

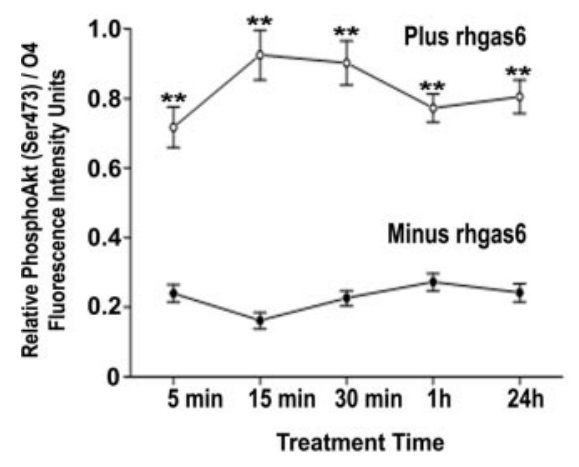

e

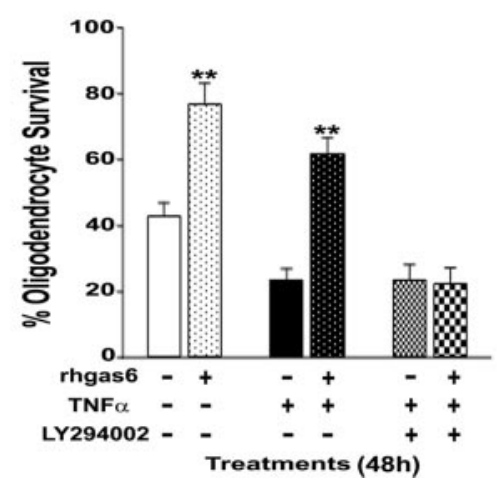

Figure 4. The rhgas 6 protective effect against TNF $\alpha$ is mediated by Akt activation and is inhibited by treatment with the PI3 kinase inhibitor LY294002. All human oligodendrocytes were grown for $5 \mathrm{~d}$ in CD medium plus rhgas6. $\boldsymbol{a}$, Human oligodendrocytes were washed twice with HBSS, incubated in DMEM (without insulin, PDGF, or NT-3) and $100 \mathrm{ng} / \mathrm{ml}$ TNF $\alpha$ in the absence or presence of rhgas6 ( $400 \mathrm{ng} / \mathrm{ml}$ ) for $15 \mathrm{~min}$, and fixed with $4 \%$ paraformaldehyde. Oligodendrocytes were double-labeled sequentially with the 04 (red) and phosphoAkt Ser473 (green) antibodies. Nuclei were labeled with DAPI (blue). Confocal microscopy was performed, and images were collected in Z-series. Scale bar, $8 \mu \mathrm{m}$. Low-magnification images (red/green merge) were obtained with a $20 \times$ objective. Scale bar, $10 \mu \mathrm{m} . \boldsymbol{b}$, phosphoAkt Ser473 and 04 immunofluorescence measurements were obtained from 80 cells in 15 random, $200 \times$ magnification microscopic fields by NIH ImageJ software. Data are expressed as relative fluorescence intensity (mean $\pm S D$ ) from one of three independent experiments with similar results $\left({ }^{* *} p<0.0001\right.$, ANOVA). Data are shown relative to minus gas 6 (set as 1.0); TNF $\alpha$ alone did not significantly (ns) activate phosphoAkt at 15 min. c, Human oligodendrocytes grown in rhgas 6 for $5 \mathrm{~d}$ were placed overnight in DMEM, washed twice with HBSS, treated with minus or plus gas 6 supplemented with $10 \mathrm{ng} / \mathrm{ml} \mathrm{IGF-1,} 5 \mathrm{ng} / \mathrm{ml} \mathrm{NT}-3$, or $10 \mathrm{ng} / \mathrm{ml} \mathrm{PDGF}$ for $15 \mathrm{~min}$, and then stopped by the addition of $4 \%$ paraformaldehyde. PhosphoAkt Ser473 and 04 immunofluorescence measurements were obtained from 32 cells in 10 random, $200 \times$ magnification microscopic fields by NIH ImageJ software, and data are expressed as relative fluorescence intensity

ity by ligand activation of the receptor tyrosine kinase Axl. Human oligodendrocytes are more dependent on rhgas6 for their survival than murine oligodendrocytes, but, when oligodendrocytes are challenged with TNF $\alpha$, rhgas 6 is highly effective in maintaining survival in both species. The inability of rhgas6 to protect $A x l^{-/-}$oligodendrocytes from $\operatorname{TNF} \alpha-$ induced toxicity further supports our conclusion that Axl is the predominant receptor through which rhgas6 signals in oligodendrocytes. Axl receptor activation was shown to be more responsive to low doses of rhgas6 (Nagata et al., 1996), and our observation that as little as $0.35 \mathrm{~nm}$ rhgas6 protected oligodendrocytes from $\mathrm{TNF} \alpha$-induced cytotoxicity supports that study.

In a previous study, we showed that two independent inhibitors of PI3 kinase blocked the protective effect of rhgas 6 and speculated that rhgas6 was signaling to Akt (Shankar et al., 2003). In this study, we demonstrate that rhgas 6 signaling through the Axl receptor results in increased Akt phosphorylation at serine 473 in both human and murine oligodendrocytes and that the Akt activation was maintained when oligodendrocyte cultures were cotreated with $\mathrm{TNF} \alpha$ and rhgas6. In addition, the rhgas 6 protective effect was abrogated in oligodendrocytes from both $A x l^{-/-}$and $A k t 1^{-/-}$mice, further demonstrating the importance of the Axl receptor and Akt 1 in protection against $\mathrm{TNF} \alpha$. Several growth factors, including PDGF, high doses of insulin, and NT-3, increase cell survival by activating Akt. Doses of insulin above $250 \mathrm{ng} / \mathrm{ml}$ activate the IGF1R and lead to sustained activation of Akt (Ness and Wood, 2002). In our studies, the absence of insulin, or insulin concentrations

(mean \pm SD) from one of two independent experiments with similar results. $\boldsymbol{d}$, Human oligodendrocytes placed overnight in DMEM, washed twice with HBSS, and treated with minus or plus gas 6 for $5 \mathrm{~min}, 15 \mathrm{~min}, 30 \mathrm{~min}, 1 \mathrm{~h}$, and $24 \mathrm{~h}$. PhosphoAkt Ser473 and 04 immunofluorescence measurements were obtained from 32 cells in 10 random, $200 \times$ magnification microscopic fields by NIH ImageJ software, and data are expressed as relative fluorescence intensity (mean \pm SD) from one of two independent experiments with similar results (** $p<0.0001$, ANOVA).e, Human oligodendrocytes grown as above were washed with HBSS and incubated for $48 \mathrm{~h}$ in TNF $\alpha(100 \mathrm{ng} / \mathrm{ml})$ in the presence or absence of rhgas6 $(400 \mathrm{ng} / \mathrm{ml})$ with or without the PI3 kinase/Akt inhibitor LY294002 (10 $\mu \mathrm{M})$. Data are shown as percentage oligodendrocyte survival (mean \pm SD with $\sim 400$ $\mathrm{O4}^{+}$cells counted from 20 random, $200 \times$ microscopic fields per treatment condition from duplicate wells) obtained from one of two independent experiments $\left({ }^{* *} p<0.0001\right.$, ANOVA). 
a

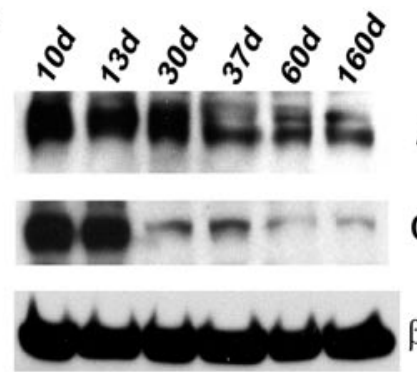

C
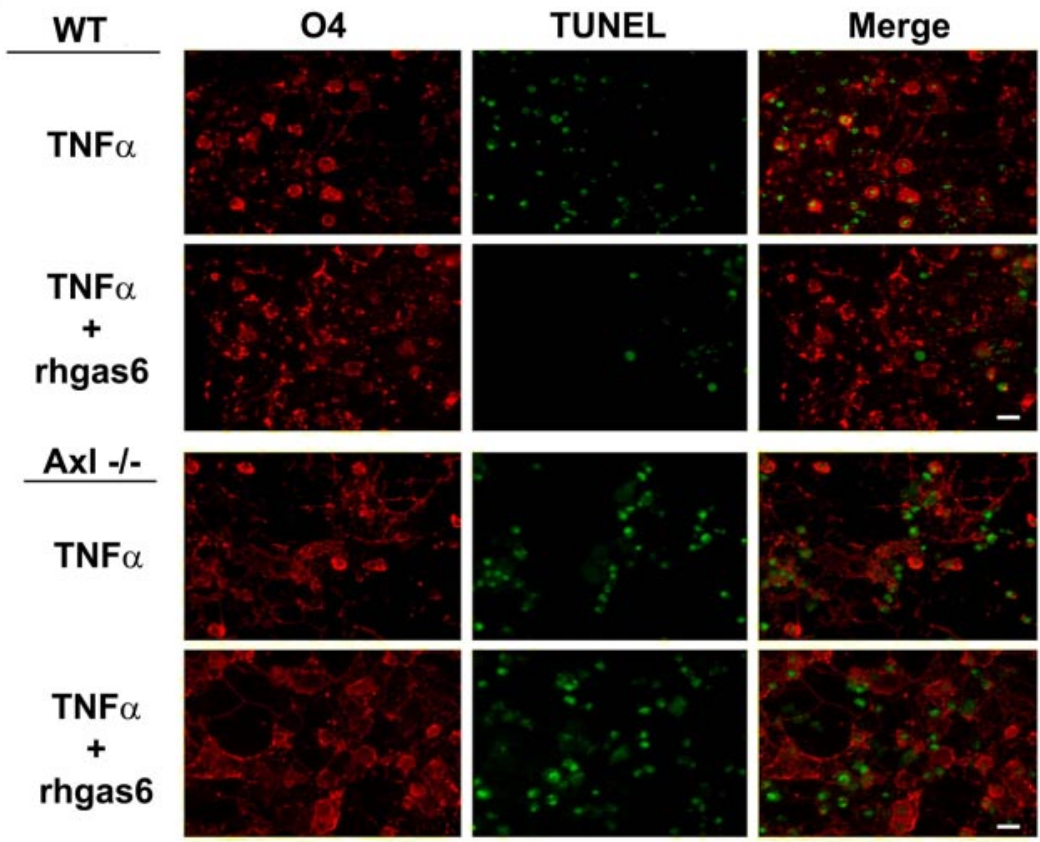

b

Axl

Gas6

$\beta$-Tubulin
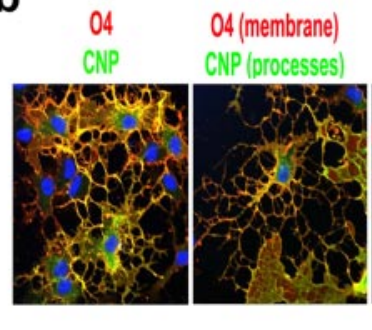

04 GFAP
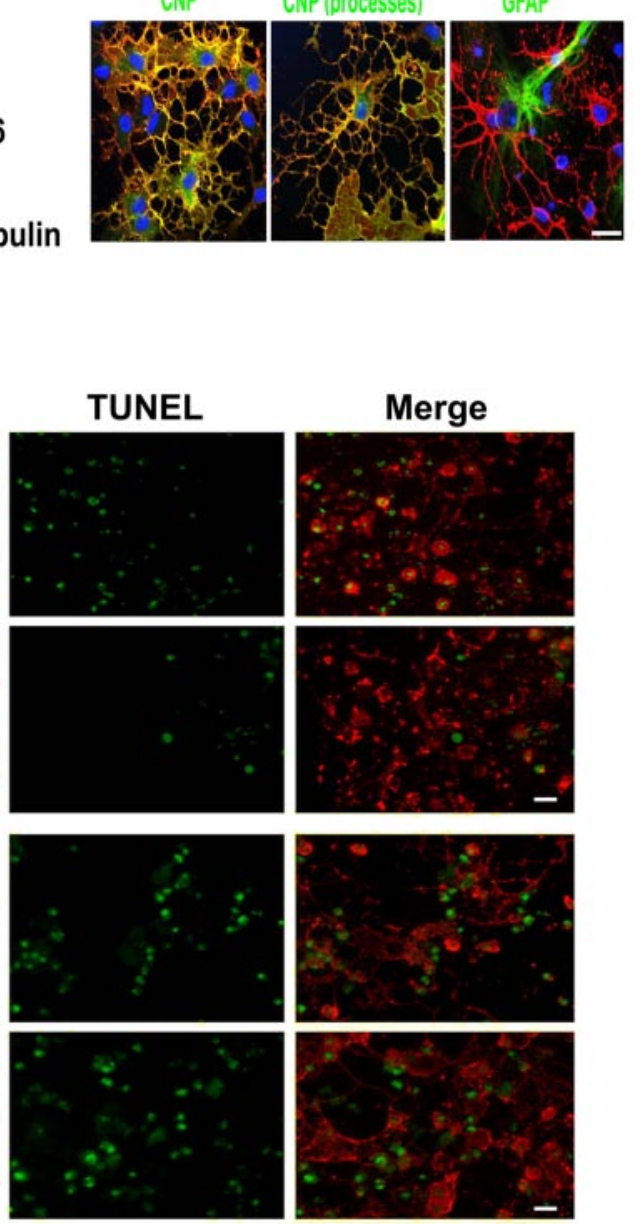

d

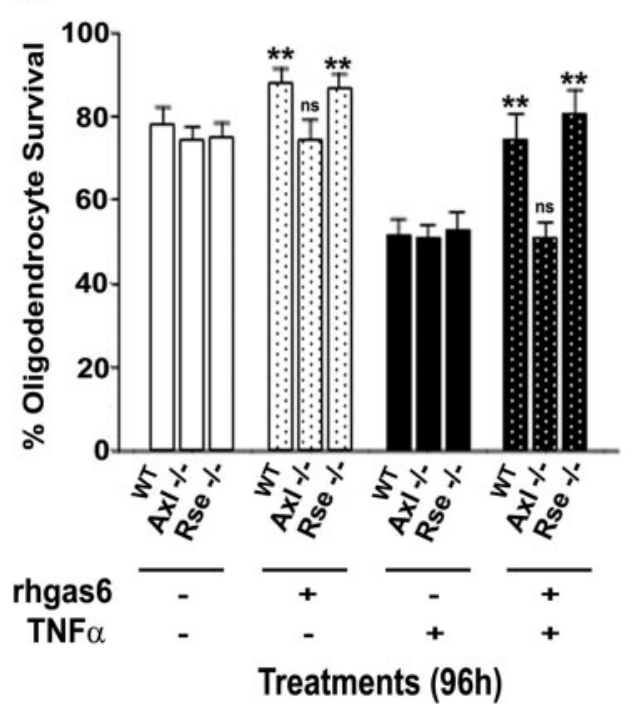

e

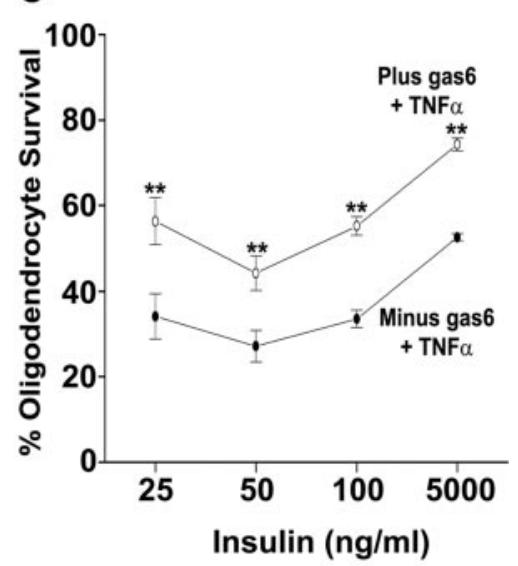

Figure 5. rhgas6 protects oligodendrocytes from WT and $R s e^{-/-}$but not oligodendrocytes from $A x l^{-/-}$mice against TNF $\alpha$ induced apoptotic cell death. $\boldsymbol{a}$, Developmental expression of Axl and Gas 6 in mouse brain. A total of $50 \mu \mathrm{g}$ of whole mouse brain protein homogenate was loaded per lane. Blots were incubated with affinity-purified antibodies Axl polyclonal antibodies (1:500; Amgen), Gas6 polyclonal antibodies (1:1000; Amgen), or $\beta$-tubulin (1:1000; Sigma). Axl migrates at $140 \mathrm{kDa}$, Gas6 at $86 \mathrm{kDa}$, and $\beta$-tubulin at $55 \mathrm{kDa}$. Visualization is by ECL. $\boldsymbol{b}$, Mouse cortical oligodendrocytes grown for $7 \mathrm{~d}$ in culture were triple labeled with 04 (red), CNP (green), or GFAP (green) and DAPI (blue). Middle panel shows membrane extensions typical of mouse oligodendrocytes in vitro. Merged images show healthy oligodendrocytes with minimal astrocyte contamination. Scale bar, $16 \mu \mathrm{m} . \boldsymbol{c}, \boldsymbol{d}$, Rhgas6 protects oligodendrocytes from $A x I^{+/+}$and $R s e^{-/-}$but not oligodendrocytes from $A x I^{-/-}$mice against TNF $\alpha$-induced below $100 \mathrm{ng} / \mathrm{ml}$, dramatically decreased oligodendrocyte survival in both human and murine oligodendrocyte cultures. In contrast, oligodendrocytes maintained in rhgas6 with low concentrations (25-100 $\mathrm{ng} / \mathrm{ml}$ ) of insulin in the CD medium significantly reduced the numbers of TUNEL $^{+}$apoptotic cells. This demonstrates that rhgas6 potently increases oligodendrocyte survival independent of the insulin/IGF1R signaling.

Oligodendrocytes are sensitive to $\mathrm{TNF} \alpha$-mediated cytotoxicity in vitro and in vivo. In vitro administration of $\mathrm{TNF} \alpha$ induced apoptotic cell death of primary oligodendrocytes (Selmaj and Raine, 1988; D'Souza et al., 1996; Scurlock and Dawson, 1999; Hisahara et al., 2000; Takano et al., 2000). In vivo, elevated levels of TNF $\alpha$ are found in multiple sclerosis plaques and in experimental autoimmune encephalomyelitis lesions (Powell et al., 1990; Genain et al., 1995; Brosnan and Raine, 1996). Transgenic mice expressing TNF $\alpha$ in the CNS showed increased oligodendrocyte apoptosis and primary demyelination (Akassoglou et al., 1997). TNF $\alpha$ mediated apoptosis occurs as a result of TNF $\alpha$ binding to the TNFR1 receptor, which recruits FAS-associated death domain FADD, receptor-interacting protein RIP1, and TNF receptor-associated factor TRAF2/5 via the adaptor protein TNFRassociated death domain-containing protein TRADD (Hsu et al., 1996). FADD recruits and activates caspase- 8 , resulting in the cleavage and activation of caspase- 3 and caspase-7 and subsequent apoptosis. Our studies indicate that the addition of $\mathrm{TNF} \alpha$ to human and murine oligodendro-

apoptosis. Oligodendrocytes isolated from postnatal day 1 WT $A x I^{-/-}$, and $R s e^{-/-}$mice were grown for $5 \mathrm{~d}$, washed with HBSS, and incubated for $96 \mathrm{~h}$ in DMEM (with $5000 \mathrm{ng} / \mathrm{ml}$ insulin) plus TNF $\alpha(100 \mathrm{ng} / \mathrm{ml})$ in the presence or absence of rhgas6 (400 ng/ml). 04 and TUNEL labeling was performed sequentially, and low-magnification images $(200 \times)$ were obtained on an Olympus Optical 1X70 microscope with a $20 \times$ objective (c). Scale bar, $10 \mu \mathrm{m}$. Results in $\boldsymbol{d}$ are based on duplicate wells of 20 random, $200 \times$ microscopic fields containing $\sim 600$ oligodendrocytes in total. Data are shown as percentage oligodendrocyte survival (mean \pm SD) of one of three independent experiments with similar results $\left({ }^{* *} p<0.0001\right.$, ANOVA; ns, not significant). $e$, Rhgas6 protects murine cortical oligodendrocytes from $\operatorname{TNF} \alpha$-induced cell death independent of insulin-activated IGFR. Oligodendrocytes were washed and placed in CD medium in the absence (minus) or presence (plus) of rhgas $6(400 \mathrm{ng} / \mathrm{ml} ; 5.6$ $\mathrm{nM}$ ) with varying concentrations of insulin $(25-5000 \mathrm{ng} / \mathrm{ml})$ and in the presence and absence of $100 \mathrm{ng} / \mathrm{ml} \mathrm{TNF} \alpha$ for $48 \mathrm{~h}$. Data are shown as percentage oligodendrocyte survival (mean $\pm S D$ ) of one of three independent experiments with similar results $\left({ }^{* *} p<0.0001\right.$, ANOVA). 


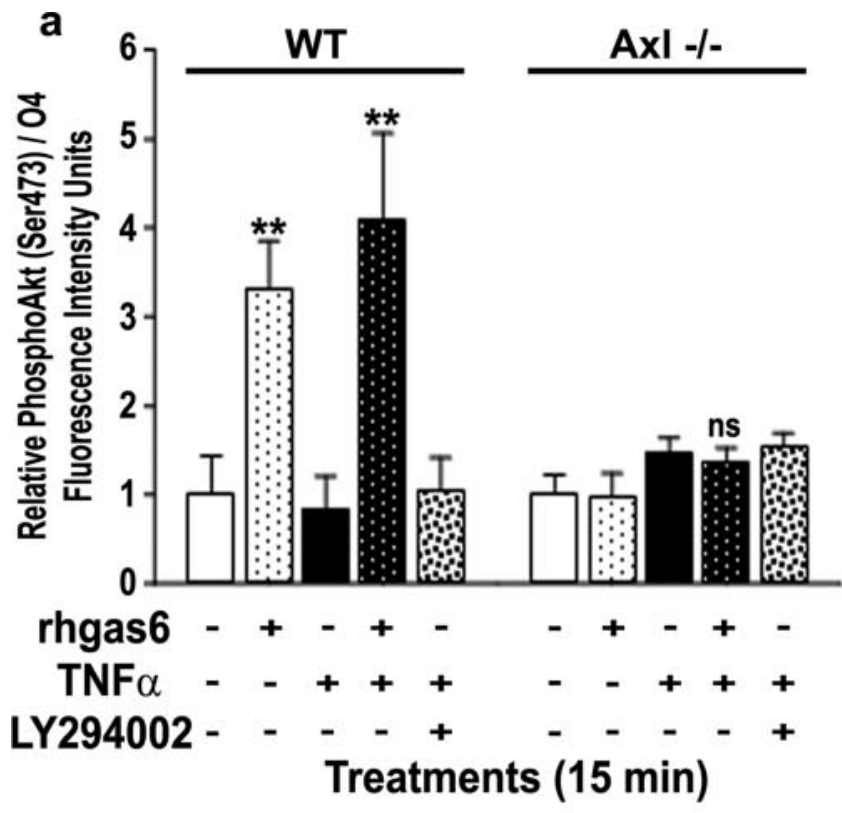

b

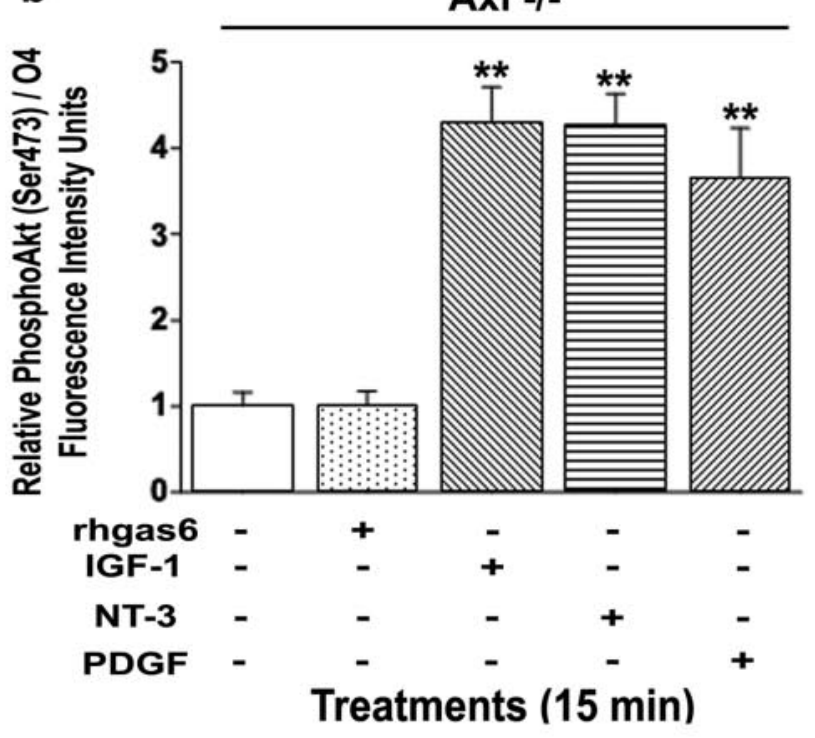

C

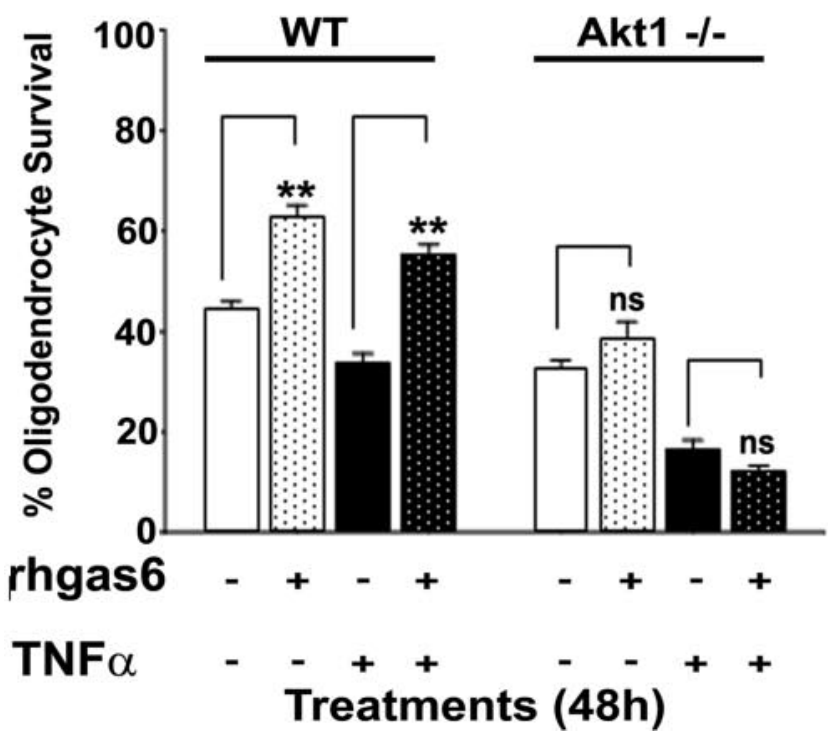

cytes induces apoptosis. In our cultures, TNF $\alpha$ activated caspase- 8 and caspase- 3 and increased the number of active cleaved caspase- $3^{+}$TUNEL $^{+}$oligodendrocytes. The effect was blocked with either the caspase- 8 inhibitor IETD-fmk or the pancaspase inhibitor zVAD-fmk. The presence of rhgas6 in TNF $\alpha$ treated oligodendrocyte cultures significantly protected against caspase activation and cell death. There was an additional reduction in $\mathrm{TUNEL}^{+}$oligodendrocytes when the caspase inhibitors were added to the rhgas 6 , TNF $\alpha$-containing medium. However, rhgas6 was more effective at maintaining oligodendrocyte survival than the addition of the caspase inhibitors alone. This suggests that rhgas 6 does not act to directly inhibit caspase activation but works upstream to activate signaling pathways such as PI3K/ Akt. This was supported by our observation that increased phosphoAkt Ser473 was observed in both human and murine oligodendrocytes 15 min after the addition of TNF $\alpha$ and rhgas 6 but not TNF $\alpha$ alone. Furthermore, the addition of the PI3 kinase inhibitor LY294002 blocked the protective effect of rhgas6 and the observed increase in phosphoAkt. Our observation of Akt activation in the rhgas6- and TNF $\alpha$-treated human and murine oligodendrocyte cultures is supported by an in vitro study that demonstrated that, after gas6 stimulation, the Axl receptor undergoes autophosphorylation, resulting in tyrosine phosphorylation at three sites (Braunger et al., 1997). Two of the tyrosines phosphorylated form part of a consensus sequence pYXXM that may recruit PI3 kinase by direct binding of the Src homology 2 domain of the p85 subunit of PI3 kinase to Axl.

Axl, Rse, and Mer single, double, and triple knock-out mice have been generated and are viable but have varying degrees of impairments in cell viability and homeostasis (Lu et al., 1999; D'Cruz et al., 2000). The triple knock-out mice have neurologic abnormalities, major organ defects, physiological deficits, and autoimmune defects. Altered histology, increased apoptosis, and cellular degeneration are apparent in the CNS, and male mice produce no sperm (Lu et al., 1999; Lu and Lemke, 2001). To gain an understanding of the contribution of Axl or Rse receptors to

$\leftarrow$

Figure 6. rhgas6 activates Akt in WT but not in $A x l^{-/-}$murine oligodendrocytes; the survival effect requires activation of Akt1. a, Murine oligodendrocyte cultures (day 7) were placed overnight in DMEM, washed with HBSS, and incubated in $100 \mathrm{ng} / \mathrm{ml} \mathrm{TNF} \alpha$ in DMEM (without insulin, PDGF, or NT-3), in the absence or presence of rhgas $6(400 \mathrm{ng} / \mathrm{ml})$ for $15 \mathrm{~min}$. Oligodendrocytes were triple labeled with the 04, phosphoAkt Ser473, and DAPI. phosphoAkt Ser473 and 04 immunofluorescence measurements were obtained from 35 cells in 10 random, $200 \times$ magnification microscopic fields by NIH ImageJ software. Data are expressed as relative fluorescence intensity (mean $\pm S D$ ) from one of three independent experiments with similar results. Data are shown relative to minus gas6 (set as 1.0). rhgas6 treatment significantly increased phosphoAkt Ser473 expression in TNF $\alpha$-treated wild-type $A x l^{+/+}$oligodendrocytes $\left({ }^{* *} p<0.0001\right.$, ANOVA; ns, not significant). $\boldsymbol{b}$, IGF-1, NT-3, and PDGF but not rhgas 6 induce Akt phosphorylation in $\mathrm{Axl}^{-/-}$murine oligodendrocytes. Day 5 murine $A x l^{-/-}$oligodendrocytes were placed overnight in DMEM, washed twice with HBSS, and treated with DMEM only or DMEM with either $10 \mathrm{ng} / \mathrm{ml} \mathrm{IGF-1,5} \mathrm{ng/ml} \mathrm{NT-3,} 10 \mathrm{ng} / \mathrm{ml} \mathrm{PDGF}$, or $400 \mathrm{ng} / \mathrm{ml}$ rhgas 6 for 15 min. phosphoAkt Ser473 and 04 immunofluorescence measurements were obtained from 35 cells in 10 random, 200× magnification microscopic fields by NIH ImageJ software. Data are expressed as relative fluorescence intensity (mean $\pm S D$ ) from one of two independent experiments with similar results ${ }^{* *} p<0.0001$, ANOVA). c, rhgas 6 does not protect against TNF $\alpha$ induced cell death in $A k t 1^{-1-}$ oligodendrocytes. Oligodendrocytes isolated from postnatal day $1 \mathrm{Akt} 1^{-/-}$mouse brains were grown for $5 \mathrm{~d}$, washed with HBSS, and incubated for $48 \mathrm{~h}$ in CD medium containing $100 \mathrm{ng} / \mathrm{ml}$ insulin plus TNF $\alpha(100 \mathrm{ng} / \mathrm{ml})$ in the presence or absence of rhgas6 (400 ng/ml). 04 and TUNEL labeling was performed sequentially, and lowmagnification images $(200 \times)$ obtained on an Olympus Optical 1 X70 microscope with a $20 \times$ objective. Results are based on duplicate wells of 20 random, $200 \times$ microscopic fields containing $\sim 300$ oligodendrocytes in total. Data are shown as percentage oligodendrocyte survival (mean $\pm \mathrm{SD}$ ) of one of two independent experiments with similar results (ns, not significant). 
oligodendrocyte survival, we generated oligodendrocyte cultures from Axl and Rse single knock-outs. Oligodendrocyte cultures from the $A x l^{-/-}$or $\mathrm{Rse}^{-/-}$mouse brains appeared morphologically similar to the WT and exhibited normal survival and differentiation in culture medium supplemented with insulin, PDGF, and NT-3. However, when oligodendrocytes were challenged with $\mathrm{TNF} \alpha$, the absence of signaling through the Axl receptor prevented rhgas6 from exerting its survival effect, supporting an important role for Axl in cell survival.

The data obtained from the TNF $\alpha$-treated differentiated oligodendrocytes from the Axl null mice strongly support our hypothesis that Axl is the primary receptor activated in response to low doses of rhgas6. Although we cannot rule out a role for the Rse or Mer receptors, we did not observe a significant change in cell survival in the Rse null oligodendrocytes expressing functional Axl and Mer receptors. Furthermore, examination of total brain homogenates from the $A x l^{+/+}$and $A x l^{-/-}$mice did not indicate the upregulation of either the Rse or Mer receptor in the null animals (data not shown).

Western blot analysis of mouse brain homogenates prepared at several development ages determined that gas6 expression paralleled Axl expression, peaking early in development and leveling off in the mature animal. Several studies have demonstrated that gas6 is expressed and secreted by both neurons and endothelial cells and that gas6 is abundantly present in the CNS (Crosier and Crosier, 1997; Prieto et al., 2000). The expression of gas6 and Axl in adult animals suggests that the gas6/Axl signaling pathway may be able to protect cells from injury. Furthermore, the downstream Akt signaling pathway can be activated to protect against stress induced by insufficient trophic support or the release of cytotoxic cytokines. In summary, our results demonstrate that rhgas6 potently inhibits TNF $\alpha$-induced oligodendrocyte apoptosis and identifies the gas6/Axl/PI3 kinase/Akt1 signaling pathway as an important mediator of oligodendrocyte survival after cellular stress and cytokine challenge.

\section{References}

Akassoglou K, Probert L, Kontogeorgos G, Kollias G (1997) Astrocytespecific but not neuron- specific transmembrane TNF triggers inflammation and degeneration in the central nervous system of transgenic mice. J Immunol 158:438-445.

Armstrong RC (1998) Isolation and characterization of immature oligodendrocyte lineage cells. Methods 16:282-292.

Bansal R, Warrington AE, Gard AL, Ranscht B, Pfeiffer SE (1989) Multiple and novel specificities of monoclonal antibodies $\mathrm{O} 1, \mathrm{O} 4$, and $\mathrm{R}-\mathrm{mAb}$ used in the analysis of oligodendrocyte development. J Neurosci Res 24:548-557.

Bitsch A, Kuhlmann T, Da Costa C, Bunkowski S, Polak T, Bruck W (2000) Tumor necrosis factor alpha mRNA expression in early multiple sclerosis lesions: correlation with demyelinating activity and oligodendrocyte pathology. Glia 29:366-375.

Braunger J, Schleithoff L, Schulz AS, Kessler H, Lammers R, Ullrich A, Bartram CR, Janssen JW (1997) Intracellular signaling of the Ufo/Axl receptor tyrosine kinase is mediated mainly by a multi-substrate dockingsite. Oncogene 14:2619-2631.

Brosnan CF, Raine CS (1996) Mechanisms of immune injury in multiple sclerosis. Brain Pathol 6:243-257.

Crosier KE, Crosier PS (1997) New insights into the control of cell growth; the role of the Axl family. Pathology 29:131-135.

Datta SR, Brunet A, Greenberg ME (1999) Cellular survival: a play in three Akts. Genes Dev 13:2905-2927.

D'Cruz PM, Yasumura D, Weir J, Matthes MT, Abderrahim H, LaVail MM, Vollrath D (2000) Mutations of the receptor tyrosine kinase gene Mertk in the retinal dystrophic RCS rat. Hum Mol Genet 9:645-651.

D’Souza SD, Alinauskas KA, Antel JP (1996) Ciliary neurotrophic factor selectively protects human oligodendrocytes from tumor necrosis factormediated injury. J Neurosci Res 43:289-298.

Franke TF, Kaplan DR, Cantley LC (1997) PI3K: downstream AKTion blocks apoptosis. Cell 88:435-437.

Gard AL, Pfeiffer SE (1989) Oligodendrocyte progenitors isolated directly from developing telencephalon at a specific phenotypic stage: myelinogenic potential in a defined environment. Development 106:119-132.

Genain CP, Roberts T, Davis RL, Nguyen MH, Uccelli A, Faulds D, Li Y, Hedgpeth J, Hauser SL (1995) Prevention of autoimmune demyelination in non-human primates by a cAMP-specific phosphodiesterase inhibitor. Proc Natl Acad Sci USA 92:3601-3605.

Hasanbasic I, Cuerquis J, Varnum B, Blostein MD (2004) Intracellular signaling pathways involved in Gas6-Axl-mediated survival of endothelial cells. Am J Physiol Heart Circ Physiol 287:H1207-H1213.

Hisahara S, Araki T, Sugiyama F, Yagami K, Suzuki M, Abe K, Yamamura K, Miyazaki J, Momoi T, Saruta T, Bernard CCA, Okano H, Miura M (2000) Targeted expression of baculovirus p35 caspase inhibitor in oligodendrocytes protects mice against autoimmune-mediated demyelination. ЕMBO J 19:341-348.

Hsu H, Shu HB, Pan MG, Goeddel D (1996) TRADD-TRAF2 and TRADDFADD interactions define two distinct TNF receptor 1 signal transduction pathways. Cell 84:299-308.

Jones SM, Klinghoffer R, Prestwich GD, Toker A, Kazlauskas (1999) A PDGF induces an early and a late wave of PI 3-kinase activity, and only the late wave is required for progression through G1. Curr Biol 9:512-521.

Kazlauskas A (1994) Receptor tyrosine kinases and their targets. Curr Opin Genet Dev 4:5-14.

Knapp PE, Bartlett WP, Skoff RP (1987) Cultured oligodendrocytes mimic in vivo phenotypic characteristics: cell shape, expression of myelinspecific antigens, and membrane production. Dev Biol 120:356-365.

Li R, Chen J, Hammonds G, Phillips H, Armanini M, Wood P, Bunge R, Godowski PJ, Sliwkowski MX, Mather JP (1996) Identification of Gas6 as a growth factor for human Schwann cells. J Neurosci 16:2012-2019.

Ling L, Templeton D, Kung HJ (1996) Identification of the major autophosphorylation sites of Nyk/Mer, an NCAM-related receptor tyrosine kinase. J Biol Chem 271:18355-18362.

Lu Q, Lemke G (2001) Homeostatic regulation of the immune system by receptor tyrosine kinases of the Tyro 3 family. Science 293:306-311.

Lu Q, Gore M, Zhang Q, Camenisch T, Boast S, Casagranda F, Lai C, Skinner MK, Klein R, Matsushima GK, Earp HS, Goff SP, Lemke G (1999) Tyro-3 family receptors are essential regulators of mammalian spermatogenesis. Nature 398:723-728.

Nagata K, Ohashi K, Nakano T, Arita H, Zong C, Hanafusa H, Mizuno K (1996) Identification of the product of growth arrest-specific gene 6 as a common ligand for Axl, Sky, and Mer receptor tyrosine kinases. J Biol Chem 271:30022-30027.

Ness JK, Wood TL (2002) Insulin-like growth factor I, but not neurotrophin-3, sustains Akt activation and provides long-term protection of immature oligodendrocytes from glutamate-mediated apoptosis. Mol Cell Neurosci 20:476-488.

Powell MB, Mitchell D, Lederman J, Buckmeier J, Zamvil SS, Graham M, Ruddle NH, Steinman L (1990) Lymphotoxin and tumor necrosis factor-alpha production by myelin basic protein-specific $\mathrm{T}$ cell clones correlates with encephalitogenicity. Int Immunol 2:539-544.

Prieto A, Weber JL, Lai C (2000) Expression of the receptor protein tyrosine kinase Tyro3, Axl and Mer in the developing rat central nervous system. J Comp Neurol 425:295-314.

Raible DW, McMorris FA (1989) Cyclic AMP regulates the rate of differentiation of oligodendrocytes without changing the lineage commitment of their progenitors. Dev Biol 133:437-446.

Rezaie P, Dean A (2002) Periventricular leukomalacia, inflammation and white matter lesions within the developing nervous system. Neuropathology 22:106-132.

Scurlock B, Dawson G (1999) Differential responses of oligodendrocytes to TNF and other pro-apoptotic agents: role of ceramide in apoptosis. J Neurosci Res 55:514-522.

Selmaj KW, Raine CS (1988) Tumor necrosis factor mediates myelin and oligodendrocyte damage in vitro. Ann Neurol 23:339-346.

Shankar SL, O'Guin K, Cammer M, McMorris FA, Stitt TN, Basch RS, Varnum B, Shafit- Zagardo B (2003) The growth arrest-specific gene 
product Gas6 promotes the survival of human oligodendrocytes via a phosphatidylinositol 3-kinase-dependent pathway. J Neurosci 23:4208-4218.

Sommer I, Schachner M (1981) Monoclonal antibodies (O1 to O4) to oligodendrocyte cell surfaces: an immunocytological study in the central nervous system. Dev Biol 83:311-327.

Sperber BR, McMorris FA (2001) Fyn tyrosine kinase regulates oligodendroglial cell development but is not required for morphological differentiation of oligodendrocytes. J Neurosci Res 63:303-312.

Stitt TN, Conn G, Gore M, Lai C, Bruno J, Radziejewski C, Mattsson K, Fisher J, Gies DR, Jones PF, Masiakowski P, Ryan TE, Tobkes NJ, Chen DH, DiStefano PS, Long GL, Basilico C, Goldfarb MP, Lemke G, Glass DJ, Yancopoulos GD (1995) The anticoagulation factor protein S and its relative, Gas6, are ligands for the Tyro 3/Axl family of receptor tyrosine kinases. Cell 80:661-670.

Takano R, Hisahara S, Namikawa K, Kiyama, Okano H, Miura M (2000) NGF protects oligodendrocytes from TNF-alpha induced injury through Akt-mediated signaling mechanisms. J Biol Chem 275:16360-16365.

Varnum BC, Young C, Elliott G, Garcia A, Bartley TD, Fridell YW, Hunt RW, Trail G, Clogston C, Toso RJ, Yanagihara D, Bennett L, Sylber M, Merewether LA, Tseng A, Escobar E, Liu ET, Yamane HK (1995) Axl receptor tyrosine kinase stimulated by the vitamin K-dependent protein encoded by growth-arrest-specific gene 6. Nature 373:623-626.

Vemuri GS, McMorris FA (1996) Oligodendrocytes and their precursors require phosphatidylinositol 3-kinase signaling for survival. Development 122:2529-2537. 